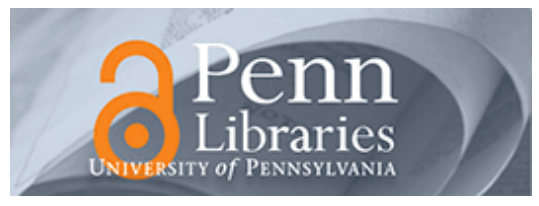

University of Pennsylvania

ScholarlyCommons

Accounting Papers

Wharton Faculty Research

8-2013

\title{
The Relation Between Equity Incentives and Misreporting: The Role of Risk-Taking Incentives
}

Christopher S. Armstrong

University of Pennsylvania

David F. Larcker

Gaizka Ormazabal

Daniel J. Taylor

University of Pennsylvania

Follow this and additional works at: https://repository.upenn.edu/accounting_papers

Part of the Accounting Commons, and the Management Sciences and Quantitative Methods Commons

\section{Recommended Citation}

Armstrong, C. S., Larcker, D. F., Ormazabal, G., \& Taylor, D. J. (2013). The Relation Between Equity

Incentives and Misreporting: The Role of Risk-Taking Incentives. Journal of Financial Economics, 109 (2), 327-350. http://dx.doi.org/10.1016/j.jfineco.2013.02.019

This paper is posted at ScholarlyCommons. https://repository.upenn.edu/accounting_papers/107

For more information, please contact repository@pobox.upenn.edu. 


\title{
The Relation Between Equity Incentives and Misreporting: The Role of Risk- Taking Incentives
}

\author{
Abstract \\ Prior research argues that a manager whose wealth is more sensitive to changes in the firm's stock price \\ has a greater incentive to misreport. However, if the manager is risk-averse and misreporting increases \\ both equity values and equity risk, the sensitivity of the manager's wealth to changes in stock price \\ (portfolio delta) will have two countervailing incentive effects: a positive "reward effect" and a negative \\ "risk effect." In contrast, the sensitivity of the manager's wealth to changes in risk (portfolio vega) will \\ have an unambiguously positive incentive effect. We show that jointly considering the incentive effects of \\ both portfolio delta and portfolio vega substantially alters inferences reported in prior literature. Using \\ both regression and matching designs, and measuring misreporting using discretionary accruals, \\ restatements, and enforcement actions, we find strong evidence of a positive relation between vega and \\ misreporting and that the incentives provided by vega subsume those of delta. Collectively, our results \\ suggest that equity portfolios provide managers with incentives to misreport when they make managers \\ less averse to equity risk.
}

\section{Keywords}

equity incentives, executive compensation, misreporting, earnings management, restatements, SEC enforcement actions

\section{Disciplines}

Accounting | Management Sciences and Quantitative Methods 


\title{
The Relation Between Equity Incentives and Misreporting: The Role of Risk-Taking Incentives
}

\author{
Christopher S. Armstrong \\ carms@wharton.upenn.edu \\ The Wharton School \\ University of Pennsylvania \\ David F. Larcker* \\ Larcker_David@gsb.stanford.edu \\ Graduate School of Business \\ Stanford University \\ Rock Center for Corporate Governance
}

Gaizka Ormazabal

gormazabal@iese.edu

IESE Business School

University of Navarra

Daniel J. Taylor

dtayl@wharton.upenn.edu

The Wharton School

University of Pennsylvania

Draft: November 20, 2012

\footnotetext{
*Corresponding author. We thank Wayne Guay for sharing his estimates and code to calculate the sensitivity of executives' equity portfolios to changes in stock price and risk. Armstrong and Taylor thank the Dean's Research fund at The Wharton School for funding a portion of the project. Larcker thanks the Joseph and Laurie Lacob Faculty Fellowship. Ormazabal thanks the Ramon y Cajal Fellowship. Additionally, we thank Bill Schwert (editor), an anonymous referee, and Wayne Guay, Cathy Schrand, and Ro Verrecchia for helpful comments, and David Li, Scott Schmeling, David Wu, and Yushu Zheng for research assistance.
} 


\title{
The Relation Between Equity Incentives and Misreporting: The Role of Risk-Taking Incentives
}

\begin{abstract}
Prior research argues that a manager whose wealth is more sensitive to changes in the firm's stock price has a greater incentive to misreport. However, if the manager is risk-averse and misreporting increases both equity values and equity risk, the sensitivity of the manager's wealth to changes in stock price (portfolio delta) will have two countervailing incentive effects: a positive "reward effect" and a negative "risk effect." In contrast, the sensitivity of the manager's wealth to changes in risk (portfolio vega) will have an unambiguously positive incentive effect. We show that jointly considering the incentive effects of both portfolio delta and portfolio vega substantially alters inferences reported in prior literature. Using both regression and matching designs, and measuring misreporting using discretionary accruals, restatements, and enforcement actions, we find strong evidence of a positive relation between vega and misreporting and that the incentives provided by vega subsume those of delta. Collectively, our results suggest that equity portfolios provide managers with incentives to misreport when they make managers less averse to equity risk.
\end{abstract}

JEL Classification: J33, G34, M41, M52

Keywords: Equity Incentives, Executive Compensation, Misreporting, Earnings Management, Restatements, SEC Enforcement Actions 


\section{Introduction}

Although a considerable literature examines the relation between managerial equity incentives and financial misreporting, the empirical results have been mixed. The conceptual foundation of this literature is based on the notion that misreporting increases stock price, thereby increasing the value of the manager's equity portfolio. Prior studies assume that a manager whose wealth is more sensitive to changes in stock price benefits more from misreporting. Accordingly, a number of studies test for a relation between the sensitivity of a manager's wealth to changes in stock price (portfolio delta) and misreporting. Although the majority of these prior studies predict and document a positive relation between portfolio delta and misreporting, the results across these studies vary considerably (see Table 1 for a summary of the various research designs and results in this literature). ${ }^{1}$

With rare exception, prior work focuses on how managers benefit from an increase in stock price without considering the economic consequences of any corresponding changes in firm risk. This is an important omission because there are substantial monetary and nonmonetary risks associated with the decision to misreport (e.g., Karpoff et al., 2008a, b). If managers are risk-averse, and misreporting increases both equity values and equity risk, managers will trade off any expected reward and risk associated with the misreporting decision. In this case, both the sensitivity of the manager's wealth to changes in stock price (portfolio delta) and the sensitivity of the manager's wealth to changes in risk (portfolio vega) will affect the manager's decision to misreport, but not necessarily in the same manner.

In particular, if misreporting increases equity values and equity risk, then portfolio delta will have two countervailing effects on misreporting. First, as discussed in the prior misreporting

\footnotetext{
${ }^{1}$ For example, Erickson et al. (2006), Efendi et al. (2007), and Armstrong et al. (2010) find no evidence of a relation between the sensitivity of the manager's wealth to changes in stock price and misreporting.
} 
literature, delta will encourage misreporting because delta captures the increase in value of a manager's equity portfolio from an increase in stock price - the "reward effect." Second, delta will discourage misreporting because delta amplifies the effect of equity risk on the total riskiness of a manager's equity portfolio, generally discouraging risk-averse managers from taking risky projects - the "risk effect" (e.g., Lambert, Larcker, and Verrecchia, 1991; Carpenter, 2000; Ross, 2004; Lewellen, 2006; Armstrong and Vashishtha, 2012). As a result of these two countervailing effects, the theoretical relation between portfolio delta and misreporting is ambiguous. This observation may explain why prior empirical research finds mixed evidence on the relation between portfolio delta and misreporting.

In contrast, portfolio vega unambiguously encourages misreporting. Unlike delta, portfolio vega provides managers with an incentive (or less of a disincentive in the case of a riskaverse manager) to increase firm risk. If misreporting increases both equity values and equity risk, ceteris paribus, managers with greater risk-taking incentives will be more likely to misreport because they will be less averse to the increased equity risk that accompanies misreporting. Thus, to understand the incentive effects of a manager's equity portfolio on the decision to misreport, it is necessary to simultaneously consider both the delta and vega of the portfolio. $^{2}$

In contrast to most prior research, we focus on the role of portfolio vega in influencing the decision to misreport. We first replicate prior research that examines the relation between managers' portfolio delta and each of three common measures of misreporting: discretionary

\footnotetext{
${ }^{2}$ To illustrate, consider a simple example of two Chief Executive Officers (CEOs) with very different equity portfolios. The first CEO holds in-the-money stock options that provide him with a relatively high delta and a relatively low vega. The second CEO holds at-the-money stock options that provide him with a relatively low delta and a relatively high vega. Ceteris paribus, the second CEO has a stronger incentive to assume risk associated with misreporting because at-the-money options have an intrinsic value that is insensitive to stock price declines. In contrast, the first CEO already has considerable intrinsic value, and thus will have a disincentive to take risky actions because such actions jeopardize the value of his options (i.e., a significant stock price decline will also induce a significant decline in his equity portfolio).
} 
accruals, accounting restatements, and Securities and Exchange Commission (SEC) Accounting and Auditing Enforcement Releases (AAERs). Consistent with prior research, we find evidence of a positive relation between delta and misreporting using a regression design (e.g., Bergstresser and Philippon, 2006; Burns and Kedia, 2006), but no evidence of a relation between delta and misreporting when using a matched-pair design (e.g., Erickson et al., 2006; Efendi et al., 2007; Armstrong et al., 2010). In contrast to the mixed results reported in prior literature focusing on portfolio delta, when we replace delta with vega, regardless of research design, we find strong evidence of a positive relation between vega and misreporting. Finally, when we jointly consider both delta and vega, regardless of research design, we find that vega continues to exhibit a strong positive relation with misreporting, but that delta is not incrementally related to misreporting. Consistent with misreporting affecting risk, and thus delta providing two countervailing incentive effects, our results suggest that the incentive effects of portfolio vega subsume those of portfolio delta. More specifically, absent controlling for portfolio vega, managers with high delta appear more likely to misreport not because delta provides them with incentives to misreport, but rather, because such managers also have high vega. Our results also suggest that the effect of vega on misreporting is economically large and larger than many other determinants of misreporting.

The theoretical and conceptual arguments for why equity incentives engender misreporting predict not only that managers with greater risk-taking incentives are more likely to misreport, but also that, within a firm, increases in risk-taking incentives increase the likelihood that a particular manager misreports. To examine this issue, we repeat our analyses controlling for firm fixed effects. We find that the positive relation between vega and misreporting is robust to including firm fixed effects, and that the incentive effects of portfolio delta continue to be 
subsumed by portfolio vega. These results make it less likely that vega is capturing some omitted executive or firm-specific characteristic that explains misreporting in the cross-section.

We also conduct a number of supplemental analyses to assess the sensitivity of our results to various research design choices related to the measurement of equity incentives and to better understand the nature of the relationship between equity portfolio vega and misreporting. First, we repeat our analyses considering the incentives of both the top management team and the Chief Executive Officer (CEO). Consistent with recent research that documents a role for executives other than the CEO in misreporting (e.g., Jiang et al., 2010; Feng et al., 2011), we find that our results apply to the equity incentives of both the top management team and the CEO.

Second, we repeat our analyses using several alternative measures of equity incentives used in prior research, such as the amount of equity pay, option moneyness (i.e., the intrinsic value of option holdings), option gamma (i.e., the sensitivity of the portfolio delta to changes in stock price), the number of options granted during the year, and equity ownership. Reflecting the fact that much of the prior literature does not directly focus on risk-taking incentives, many of these variables only indirectly relate to risk-taking incentives. Consistent with this interpretation, we continue to find strong evidence of a relation between portfolio vega and misreporting and no evidence of a relation between delta and misreporting after including these additional measures. We find that the amount of equity pay and option moneyness are incrementally positively related to misreporting and that option gamma, the number of options granted, and equity ownership are not incrementally related to misreporting.

Third, since portfolio vega is determined by both option grants as well as subsequent changes in stock price, we decompose vega into the portion attributable to recent performance 
and the portion attributable to features of the option grant. Our results suggest that the positive relation between vega and misreporting is driven by the component of vega attributable to the features of the grant rather than subsequent performance.

Collectively, our results suggest a more nuanced view of how equity incentives relate to misreporting. In particular, our results suggest that equity holdings provide managers with incentives to misreport not because they tie their wealth to equity values, but because they tie their wealth to equity risk.

The remainder of this paper is organized into five sections. Section 2 reviews the literature on executives' equity incentives and misreporting. Section 3 discusses our sample and variable measurement choices. Section 4 describes our research design. Section 5 presents our results, and Section 6 provides concluding remarks and discusses the limitations of our study.

\section{Prior literature}

\subsection{Financial misreporting and equity risk}

Although prior studies have discussed the potential consequences to managers found to have engaged in financial misreporting, prior literature has not focused on how the risk/reward tradeoff affects managers' incentives to misreport. Prior literature suggests two reasons why financial misreporting is associated with a manager's subjective assessment of equity risk. First, misreporting increases the likelihood of extreme negative returns. While successful misreporting temporarily inflates a stock's price, once it is detected, there is typically a significant decline in that price. For example, Feroz et al. (1991) and Dechow et al. (1996) find a negative stock return of $-9 \%$ to $-10 \%$ on the first day the SEC announces an enforcement action (AAER) against the firm. Karpoff et al. (2008a) find that firms lose, on average, $38 \%$ of their market value as a result 
of SEC enforcement actions. Similarly, Palmrose et al. (2004) document an average marketadjusted return of $-20 \%$ over a two-day announcement window for restatements associated with fraud, and Bardos et al. (2011) find that stock prices begin to decline several months in advance of the restatement announcement. Second, misreporting by its very nature decreases the quality of financial reports and obfuscates the firm's true value. As a result, the level of uncertainty in the market for the firm's shares may increase (e.g., Kravet and Shevlin, 2010; Bhattacharya et al., 2012). Thus, financial misreporting can be thought of as increasing the manager's subjective assessment of both expected equity value and expected equity risk.

\subsection{Equity incentives and risk-taking}

There is a large literature that shows that equity ownership can provide underdiversified, risk-averse managers with an incentive to reject risky, positive net present value projects. Early studies argued that one potential solution to this risk-related agency problem is to compensate risk-averse managers with stock options, because the convexity of the option's payoff can offset the manager's risk aversion (e.g., Smith and Stulz, 1985). However, subsequent studies (e.g., Lambert et al., 1991; Carpenter, 2000; Ross, 2004; Lewellen, 2006) note that stock options not only increase the convexity of the manager's payoff by increasing the sensitivity of the manager's wealth to changes in risk (vega), but also increase the sensitivity of the manager's wealth to changes in stock price (delta). These studies show that the incentive effects of delta and vega are not always reinforcing, and that the net effect of options on risk-taking incentives is theoretically ambiguous. ${ }^{3}$

\footnotetext{
${ }^{3}$ Highlighting the need to differentiate between incentives provided by delta and vega, recent studies in the broader risk-taking literature acknowledge the different theoretical predictions regarding the relationship between delta, vega, and firm risk, and account for them separately in their empirical specifications (e.g., Coles et al., 2006; Low, 2009; Armstrong and Vashishtha, 2012).
} 
With regard to the incentive effects of delta, prior theoretical studies show that delta has two countervailing effects on a risk-averse manager's decision to adopt a risky, positive net present value project. On the one hand, delta will encourage project adoption because delta captures the increase in value of the manager's wealth from an increase in stock price, or the "reward effect." On the other hand, delta will discourage project adoption because delta magnifies the effect of a change in stock price on the change in the manager's wealth, and thus magnifies the effect of stock price volatility on the volatility of the risk-averse manager's wealth, the "risk effect." As a result of these countervailing effects, for projects that increase firm risk, the net incentive effect of delta is theoretically ambiguous. In contrast, these studies show that vega provides managers with an unambiguous incentive to adopt risky projects. The intuition for this result is that vega measures the increase in the value of the manager's portfolio for an increase in firm risk. Thus, ceteris paribus, managers with high vega are less averse to risky projects than are managers with low vega, and hence will be more inclined to take risky projects. When misreporting is viewed as a special case of a risky project that increases both expected equity values and equity risk, the predictions from the risk-taking literature carry over to the incentive effects of delta and vega for misreporting. Similar to empirical studies in the broader risk-taking literature (e.g., Coles et al., 2006; Low, 2009; Chava and Purnanandam, 2010; Armstrong and Vashishtha, 2012), we acknowledge that our predictions regarding the incentive effects of delta and vega depend on whether the project — in this case misreporting — increases or decreases risk. If misreporting increases stock price but either decreases or does not affect risk, the incentive effects of delta (i.e., the "reward effect" and the "risk effect") will be reinforcing, and we expect to find a positive relation between delta and misreporting and no relation between vega and misreporting. However, if misreporting increases stock price and also 
increases risk, the incentive effects of delta will be countervailing, and we expect to find no relation between delta and misreporting and a positive relation between vega and misreporting. We believe that misreporting is best characterized as a project that increases both the level and risk of stock price, and thus expect to find that much of the incentive to misreport comes from portfolio vega. Ultimately, however, whether the incentive effects of delta are reinforcing or countervailing, and which incentives dominate — those provided by delta or vega — are empirical questions.

\subsection{Equity incentives and financial misreporting}

A large literature examines the relation between managers' equity incentives and financial misreporting (see Table 1). In general, studies in this literature predict that managerial equity holdings and the structure of their annual flow pay provides them with incentives to manipulate financial reports. For example, Bergstresser and Philippon, (2006) find evidence of a positive relation between the CEO's portfolio delta and the magnitude of the firm's discretionary accruals. Burns and Kedia (2006) find evidence of a positive relation between the CEO's portfolio delta and accounting restatements. Jiang et al. (2010) and Feng et al. (2011) extend these results by showing that the portfolio delta of other top managers (e.g., the Chief Financial Officer (CFO)) is also related to misreporting. In contrast to these studies, Efendi et al. (2007) find evidence of a positive relation between the intrinsic value or "moneyness" of the CEO's option portfolio and accounting restatements, but no relation between the CEO's portfolio delta and accounting restatements. Erickson et al. (2006) also find no evidence of a relation between either the CEO's or the top management team's portfolio delta and AAERs, and conclude that managers' equity holdings do not provide them with incentives to misreport. Similarly, 
Armstrong et al. (2010) find no evidence of a relation between the CEO's portfolio delta, and either accounting restatements, AAERs, or shareholder litigation and reach a similar conclusion.

One explanation for the mixed results documented by prior literature could be differences in sample size or research design. For example, studies that find a positive relation between portfolio delta and misreporting tend to use a regression design (e.g., Bergstresser and Philippon, 2006; Burns and Kedia, 2006), whereas studies that find no relation between portfolio delta and misreporting tend to use a matched-pair design (e.g., Erickson et al., 2006; Efendi et al., 2007; Armstrong et al., 2010). For this reason, we use both regression and matched-pair designs in our empirical tests. Another explanation for these mixed results is that misreporting increases risk, in which case, delta will have two countervailing effects on a risk-averse manager's incentives to misreport, resulting in an ambiguous net effect. In contrast, if misreporting increases risk, vega (unlike delta) is expected to provide managers with an unambiguous incentive to misreport. Therefore, in contrast to earlier studies, we focus on the relation between portfolio vega and misreporting.

Some prior studies examine how different elements of option compensation provide incentives to misreport, but do not focus specifically on the risk-taking incentives provided by portfolio vega. For example, Cheng and Farber (2008) examine the relation between misreporting and the number of options granted to managers during the year. They conjecture that "too high a level of options can induce excessive risk-taking in investment decisions ... when these investments do not produce positive returns, managers may engage in earnings management to mask underperformance." However, because options provide both delta and vega, options not do unambiguously provide incentives to take risks. Hence, the relation between vega and misreporting cannot be inferred from the relation between the number of options and 
misreporting. In this regard, our study differs from prior research in that we analyze the effect of risk-taking incentives provided by options (vega) rather than the effect of option holdings in and of themselves.

Efendi et al. (2007) focus not on the number of options but their moneyness. Specifically, they find a positive association between the value of in-the-money stock options and misreporting. However, deep in-the-money stock options generally have low vega, and do not provide strong risk-taking incentives. Therefore, even though Efendi et al. (2007) examine a specific aspect of the manager's option portfolio, their results do not provide insight on whether risk-taking incentives are associated with misreporting. Since deep in-the-money stock options generally have low vega, if anything, the evidence in Efendi et al. (2007) suggests that risktaking incentives are negatively associated with misreporting. Similarly, Burns and Kedia (2006) conjecture that option convexity provides managers with incentives to misreport. They measure option convexity as the sensitivity of portfolio delta to changes in stock price (option gamma), and find a positive association between option gamma and misreporting. However, because option gamma measures how the slope of the manager's payoff changes with respect to stock price, it fails to capture the most important feature of risk-taking incentives: how the manager's wealth is affected by changes in risk. ${ }^{4}$

\section{Sample and variable measurement}

\subsection{Sample construction}

Our tests require data on executive compensation and equity holdings, firm performance, and proxies for misreporting. We construct our sample by collecting data on executive compensation and equity holdings from Execucomp, stock returns, and financial statement

\footnotetext{
${ }^{4}$ We examine the relation between misreporting and these alternative measures of equity incentives in Section 5.
} 
information from the Center for Research in Security Prices (CRSP)/Compustat Industrial file, accounting restatements from AuditAnalytics, and SEC Accounting and Auditing Enforcement Releases from the Center for Financial Reporting and Management. Our sample is constructed as the intersection of these four data sets, and consists of 20,445 firm-years (2,446 firms) over the period 1992 to 2009.

Exесисотр. We collect data on executive compensation and equity holdings of the top five named executives (including the CEO) from Execucomp. We require data on cash compensation for the top five executives, and sufficient data to estimate the sensitivity of the value of each executive's portfolio to changes in stock price and risk, per Core and Guay (2002).

CRSP/Compustat Industrial. We require returns during the fiscal year from CRSP, and the following variables from Compustat: net income (IB); market value (PRCC_F multiplied by CSHO); book value (CEQ); total liabilities (LT); total assets (AT); receivables (RECT); gross and net plant, property, and equipment (PPEGT and PPENT); inventory (INVT); research and development expense (XRD); advertising expense (XAD); interest expense (XINT); proceeds from share and debt issuances (SSTK and DLTIS); the contribution of acquisitions to sales (AQS); positive sales (SALE); and cash flow from operations (OANCF less XIDOC). ${ }^{5}$ We also collect data on sales and cash flow from operations to estimate rolling ten-year volatilities and require sales and cash flow from operations in three of the ten years. Additionally, we eliminate firm-years with insufficient information to calculate discretionary accruals (see Section 3.2.1).

\footnotetext{
${ }^{5}$ Missing values for receivables, inventories, research and development expense, advertising expense, interest expense, proceeds from share and debt issuances, and acquisitions are set to zero.
} 
AuditAnalytics. We collect, but do not require, data on accounting restatements from AuditAnalytics. To be included in our sample, each restatement must have a start and end date. We use these dates to determine the fiscal year to which the restatement applies. A firm is classified as restating its results for a given year, if any financial results (quarterly, annual, or otherwise) are subsequently restated. This classification tracks the year(s) to which the restatement applies, rather than the year in which the restatement is announced.

Center for Financial Reporting and Management. We collect, but do not require, data on SEC Accounting and Auditing Enforcement Releases (AAERs) from the Center for Financial Reporting and Management. This database tracks all SEC enforcement releases relating to accounting fraud or misrepresentation (see Dechow et al., 2011, for a description). To be included in our sample, each AAER must refer to a specific period during which the accounting fraud or misrepresentation occurred. The firm is said to be named in an AAER during a given year if the SEC published an AAER that identifies accounting fraud or misrepresentation occurring at the firm during the year. Similar to restatements, we track the year of the misreporting, rather than the year the AAER is announced.

\subsection{Variable measurement}

\subsubsection{Measures of misreporting}

We examine the relation between equity incentives and misreporting using three measures of misreporting that are common in the literature: the absolute value of discretionary accruals (e.g., Bergstresser and Philippon, 2006; Jiang et al., 2010), accounting restatements (e.g., Burns and Kedia, 2006; Efendi et al., 2007), and AAERs (e.g., Erickson et al., 2006; Armstrong et al., 2010). Examining the relation between incentives and misreporting using three 
proxies for misreporting strengthens inferences relative to prior studies that focus exclusively on a single measure of misreporting (see Table 1). By using three measures of misreporting, we aim to show that our inferences apply to misreporting in general and are not specific to any one measure of misreporting.

Following prior literature, we construct our measure of discretionary accruals, Discretion, as the absolute value of discretionary accruals calculated from each of the following three models of accruals: (i) modified Jones (1991), (ii) Dechow and Dichev (2002), and (iii) McNichols (2002). ${ }^{6}$ Each of these models expresses noncash earnings (i.e., accruals) as a function of economic determinants. Discretionary accruals are calculated as the residual, or unexpected, accruals from each of these three models. Positive discretionary accruals are thought to be indicative of managers exercising income-increasing discretion, and negative discretionary accruals are thought to be indicative of income-decreasing discretion. As such, we follow prior literature (e.g., Bergstresser and Philippon, 2006; Jiang et al., 2010) and use the absolute value of discretionary accruals, Discretion, as our measure of misreporting. The primary advantage of using discretionary accruals as a measure of misreporting is that it is a continuous measure with considerable cross-sectional variation. The primary disadvantage of this measure is that, because Generally Accepted Accounting Principles (GAAP) provides managers with discretion in financial reporting, large discretionary accruals are not necessarily indicative of intentional misrepresentation or fraud.

Unlike discretionary accruals, an accounting restatement indicates that the firm retroactively changed its financial results. Because prior research suggests restatements can be the result of both benign errors and intentional misrepresentation, we restrict our analysis to only those restatements classified by AuditAnalytics as relating to fraud, misrepresentation, or an

\footnotetext{
${ }^{6}$ Results are robust to using the model of discretionary accruals in Larcker et al. (2007).
} 
investigation by the Public Company Accounting Oversight Board (PCAOB) (e.g., Hennes et al., 2008). The primary advantage of using restatements as a measure of misreporting is that we can identify specific instances in which financial results were misreported. The primary disadvantage is that restatements are conditional on the company either voluntarily restating or being forced to restate by the SEC. We code the variable Restatement equal to one if any of the firm's financial results (quarterly, annual, or otherwise) are subsequently restated.

Unlike discretionary accruals or restatements, AAERs are issued by the Securities and Exchange Commission during or at the conclusion of an investigation for alleged accounting and/or auditing misconduct. Using AAERs as a measure of misreporting has two advantages. First, the use of AAERs as a proxy for misreporting avoids some of the potential biases induced in samples based on voluntary restatements or on researchers' assumptions about the determinants of expected accruals. Second, AAERs are also likely to capture a group of the most egregious cases of misreporting, as the SEC has limited resources and likely pursues the most economically important cases. The primary disadvantage of using AAERs as a measure of misreporting is that AAERs are conditional on detection by the SEC. Thus, tests based on AAERs are joint tests of both misreporting and detection. We code the variable AAER equal to one if the SEC published an AAER that identifies accounting fraud or misrepresentation occurring at the firm during the year. ${ }^{7}$

\subsubsection{Measures of incentives}

Much of the research on the effect of equity incentives on misreporting uses the sensitivity of the manager's equity portfolio to changes in stock price, or portfolio delta, as the primary measure of equity incentives. However, a variety of different measures have been used

\footnotetext{
${ }^{7}$ As described below, all misreporting variables are measured in year $t$ and all incentive variables are measured in year $t-1$.
} 
in this literature (see Table 1). In general, studies in this literature use either measures of flow pay (e.g., Larcker et al., 2007), the amount of equity ownership (e.g., Cheng and Warfield, 2005), the intrinsic value of option holdings (e.g., Efendi et al., 2007), or portfolio delta either unscaled (e.g., Burns and Kedia, 2006) or scaled by pay (e.g., Bergstresser and Philippon, 2006). The lack of standardized measures of equity incentives may potentially explain the conflicting results reported in the literature. Moreover, most of these measures are not focused on how the manager's wealth is affected by changes in risk.

In our primary tests, we measure incentives using total cash compensation, the sensitivity of the manager's wealth to changes in equity price (portfolio delta), and the sensitivity of the manager's wealth to changes in equity risk (portfolio vega). Consistent with prior work, we focus on the equity incentives of the top management team (e.g., Erickson et al., 2006; Jiang et al., 2010; Feng et al., 2011). ${ }^{8}$ In particular, our measure of the top management team's portfolio delta, Delta, is the natural logarithm of one plus the average portfolio delta for the top five highest-paid executives (including the CEO). Following Core and Guay (2002), we calculate an executive's portfolio delta as the dollar change in the executive's equity portfolio for a $1 \%$ change in stock price. Similarly, our measure of the top management team's portfolio vega, $V e g a$, is the natural logarithm of one plus the average portfolio vega for the top five executives at the firm. Following Core and Guay (2002), we calculate Vega as the dollar change in the executive's equity portfolio for a 0.01 change in the firm's stock return volatility.

To assess the robustness of our results to our measurement choices, we also consider several alternative measures of incentives used in prior literature. First, we calculate both Delta and Vega using only the CEO's equity portfolio, CEODelta and CEOVega, respectively. Second,

\footnotetext{
${ }^{8}$ We consider the top management team to consist of the top five highest-paid executives, including the CEO. If the firm discloses pay or equity holdings for fewer than five executives, we calculate our measures of equity incentives using the number of top executives for which pay and equity holdings are available.
} 
we deflate Delta and Vega by either salary or cash compensation, labeled ScaledDelta and ScaledVega, respectively (e.g., Bergstresser and Philippon, 2006; Efendi et al., 2007). Third, we consider five alternative measures of incentives common in the literature: (1) EquityComp, calculated as the ratio of equity-based compensation to total compensation (e.g., Larcker et al., 2007); (2) Moneyness, calculated as the ratio of the option portfolio's intrinsic value to salary (e.g., Efendi et al., 2007); (3) Ownership, calculated as the number of options, shares of restricted stock, and shares of unrestricted stock held by the manager scaled by total shares outstanding (e.g., Cheng and Warfield, 2005); (4) Options, calculated as the number of options granted during the year as a fraction of total shares outstanding (e.g., Cheng and Farber, 2008); and (5) Gamma, calculated as the sensitivity of portfolio delta to changes in stock price (e.g., Burns and Kedia, 2006). Examining the relation between several measures of equity incentives and misreporting strengthens our inferences and helps to ensure that our results are not an artifact of specific measurement choices.

\subsection{Descriptive statistics}

Table 2 presents descriptive statistics for our sample. Panel A reports descriptive statistics for each measure of misreporting. Panel A shows that 3\% of our sample had restatements related to fraud or misrepresentation and that $2 \%$ of our sample was the subject of an SEC AAER. ${ }^{9}$ Panel A also shows that average unsigned discretionary accruals range from $7.74 \%$ to $12.21 \%$ of total assets, depending on the model. Panel B reports descriptive statistics for several firm characteristics. In particular, the average book-to-market ratio for firms in our sample is 0.5 and the average leverage (debt-to-asset) ratio is 0.52 . The average firm is approximately 26 years old and has annual sales growth of $14 \%$.

\footnotetext{
${ }^{9}$ Consistent with Hennes et al. (2008), we find that $13 \%$ of our sample restated their financial results, but that only $3 \%$ of our sample had restatements relating specifically to fraud or misreporting.
} 
Panel C reports descriptive statistics for the various incentive variables. The mean (median) of the natural logarithm of annual cash compensation and the Core-Guay portfolio sensitivities, Delta and Vega, are 6.29 (6.25), 4.46 (4.44), and 2.96 (2.98), respectively. Panel C also shows that the top five executives have a mean (median) equity-to-total pay ratio of 0.43 (0.37) and own $1.34 \%(0.70 \%)$ of the firm. Additionally, the intrinsic value of the average top five executive's option portfolio (i.e., Moneyness) is about ten times the value of his or her salary (mean Moneyness of 9.97). Panel D compares the mean and median values of the incentive variables in the full sample, the restatement sample (Restatement=1), and the AAER sample $(A A E R=1)$. Regardless of whether restatements or AAERs are used to measure misreporting, except for Ownership, the mean and median values of all of the equity incentive variables are significantly higher in the misreporting sample.

\section{Research design}

Our research design choices closely follow prior research. Specifically, we examine the relation between equity incentives and misreporting using both regression tests (e.g., Bergstresser and Philippon, 2006; Burns and Kedia, 2006) and matched-sample tests (e.g., Erickson et al., 2006; Efendi et al., 2007; Armstrong et al., 2010). For our regression tests, we replicate a representative regression used in prior research examining the relation between portfolio delta and a specific misreporting proxy. We then examine whether inferences are sensitive to controlling for risk-taking incentives (i.e., Vega), and whether within-firm variation in portfolio delta and portfolio vega explains within-firm variation in misreporting by including firm fixed effects in the specification. For our matched-sample tests, we replicate two types of matched-pair designs used in prior research: size-and-industry matched-pairs and propensity score matched-pairs. 


\subsection{Regression tests}

We estimate a series of regressions that take the form:

$$
\text { Misreporting }_{t}=\boldsymbol{\theta} \text { Incentives }_{t-1}+\boldsymbol{\beta} \text { Controls }_{t-1}+\varepsilon_{t},
$$

where Misreporting is one of three measures of misreporting (Discretion, Restatement, or $A A E R$ ), Incentives is the vector of incentive variables (CashComp, Delta, and Vega), and Controls is a vector of control variables. Consistent with prior research, all independent variables are measured one year prior to the measure of misreporting and inferences are based on standard errors clustered by firm and year (all variables are defined in Appendix A). ${ }^{10}$

Because prior studies generally focus on a single measure of misreporting and use different control variables depending on the measure of misreporting being examined, the vector of control variables, Controls, varies depending on the measure of misreporting.

Discretionary accruals. Following prior research, we estimate the relation between incentives and discretionary accruals controlling for firm size (Size), growth opportunities $(B M)$, leverage (Leverage), firm age (FirmAge), past accounting performance (ROA), past stock performance (Returns), capital intensity (Capital), and intangible assets (Intangibles). Additionally, because prior research suggests the volatility of a firm's operating environment is an important determinant of its discretionary accruals (e.g., Bergstresser and Philippon, 2006; Jiang et al., 2010), we also control for the volatility of cash flows ( $\sigma C F O)$ and the volatility of sales ( $\sigma$ Sales).

Restatements. Following prior research, we control for firm size (Size), growth opportunities $(B M)$, leverage (Leverage), firm age (FirmAge), past accounting performance (ROA), past stock

\footnotetext{
${ }^{10}$ All variables are winsorized at the 1 st and 99th percentiles.
} 
performance (Returns), capital intensity (Capital), and intangible assets (Intangibles).

Additionally, because prior research suggests that the amount of external financing (Financing), the size of any acquisition that year (Acquisition), and interest coverage (InterestCov) are important determinant of restatements (e.g., Burns and Kedia, 2006; Efendi et al., 2007), we include these variables as additional controls when estimating the relation between equity incentives and restatements.

AAERs. Following prior research, we control for firm size (Size), growth opportunities (BM), leverage (Leverage), firm age (FirmAge), past accounting performance (ROA), past stock performance (Returns), the capital intensity (Capital), and intangible assets (Intangibles). Additionally, because prior research suggests that the amount of external financing (Financing), the size of any acquisition that year (Acquisition), sales growth (SalesGrowth), and the size of firms' inventories (Inventory) and receivables (Receivables) are important determinants of AAERs (e.g., Erickson et al., 2006; Feng et al., 2011), we include these variables as additional controls when estimating the relation between equity incentives and AAERs.

We estimate Eq. (1) pooling all firms and years in our sample. When the measure of misreporting is continuous (e.g., Discretion), we estimate Eq. (1) using linear regression. When the measure of misreporting is dichotomous (e.g., AAER), we estimate Eq. (1) using probit regression. ${ }^{11}$ While estimating Eq. (1) using a pooled sample is consistent with prior research, it cannot identify whether the effect of managers' equity incentives comes from explaining variation in misreporting across firms (i.e., cross-sectional variation) or variation in misreporting

\footnotetext{
${ }^{11} \mathrm{We}$ assess statistical significance using $t$-statistics (linear specifications) and $z$-statistics (nonlinear specifications) both based on standard errors clustered by firm and year. Since $t$-statistics and $z$-statistics are based on the same asymptotic distribution (i.e., the normal), for simplicity, we refer to all test statistics as $t$-statistics.
} 
within firms (i.e., time-series variation). The distinction between variation across firms and variation within firms is important because the theoretical and conceptual arguments regarding how equity incentives relate to misreporting predict that (i) managers with greater equity incentives are more likely to misreport, which is a cross-sectional prediction, and (ii) managers who experience an increase in equity incentives are more likely to misreport, which is a timeseries prediction.

To determine whether within-firm variation in equity incentives explains within-firm variation in misreporting, we estimate an augmented version of Eq. (1) that includes firm fixed effects. This research design eliminates most of the cross-sectional variation in managers' equity incentives and relies primarily on within-firm (i.e., time-series) variation in incentives. If the relation between equity incentives and misreporting is driven primarily by cross-sectional differences in firm characteristics, then holding the firm constant, we expect to find no evidence of a relation between incentives and misreporting. However, if within-firm variation in incentives explains within-firm variation in misreporting, we expect to find a relation between incentives and misreporting holding the firm constant (i.e., including firm fixed effects).

\subsection{Matched-sample tests}

In addition to standard regression tests, we also examine the relation between equity incentives and misreporting using two sets of matched-sample tests. The first set of tests follows the outcome-based matching procedure used by Erickson et al. (2006) and Efendi et al. (2007). Specifically, we form one-to-one matched-pairs by matching each misreporting firm to a nonmisreporting firm based on industry and total assets. ${ }^{12}$ Because this matching procedure matches misreporting firms to non-misreporting firms, we construct separate matched-samples for each of

\footnotetext{
${ }^{12}$ We define industries according to the 48 Fama-French industry groups, and consider only matches where the non-misreporting firm's total assets are not more (less) than $1.3(0.7)$ times that of the misreporting firm. The matching procedure corresponds to those described in Erickson et al. (2006) and Efendi et al. (2007).
} 
our two binary measures of misreporting, Restatement and AAERs. We then test for differences in equity incentives between the misreporting sample and the matched-sample.

The second set of tests follows the propensity score matching procedure used by Armstrong et al. (2010). Specifically, we form one-to-one matched-pairs by estimating a propensity score as a function of control variables and then numerically solving for the set of matched-pairs that minimizes the difference in propensity scores and maximizes the difference in observed risk-taking incentives (Vega). ${ }^{13}$ Following Armstrong et al. (2010), in the first step we estimate the propensity score for Vega as a function of 18 control variables. ${ }^{14}$ The predicted value from this first step serves as the propensity score. In the second step, we employ a non-bipartite matching algorithm to simultaneously minimize the difference in propensity scores (i.e., the predicted level of risk-taking incentives) and maximize the difference in observed risk-taking incentives. Specifically, we divide the sample into treatment firms (firm $i$ ) and matched-sample firms (firm $j$ ) by numerically solving for the set of matches that minimizes the sum of the pairwise distance measure:

$$
\text { Distance }_{i, j}=\quad \frac{\left(\text { Pscore }_{i}-\text { Pscore }_{j}\right)^{2}}{\left(\text { Incentive }_{i}-\text { Incentive }_{j}\right)^{2}}
$$

We then assess the success of the resulting matched-pairs by testing for covariate balance between treatment firms and matched-sample firms. Specifically, we test for cross-sample differences in the values of the control variables used to calculate the propensity score. A successful match is one where cross-sample differences in the variables used to calculate the propensity score are minimal. Finally, we test for a difference in the level of misreporting between the treatment and control samples. For a successful match, where the treatment and

\footnotetext{
${ }^{13}$ The matching procedure corresponds to that described in Armstrong et al. (2010), with the exception that we construct a propensity score based on Vega rather than Delta.

${ }^{14}$ We include the union of all control variables used in our regression design as well as Delta and CashComp.
} 
control samples are similar along all measured dimensions except for observed risk-taking incentives (Vega), any difference in the level of misreporting between the two samples is attributable to the difference in risk-taking incentives (see Rosenbaum, 2002, for more details).

\section{Results}

\subsection{Regression analysis}

\subsubsection{Risk-taking incentives and discretion in reported earnings}

Table 3 presents results from using discretionary accruals to measure misreporting. Panel A presents results from estimating pooled regressions. For each measure of discretionary accruals, we estimate four regression specifications. The first two specifications consider Delta and Vega separately, and the third specification considers both variables simultaneously. To assess the relative economic magnitude of the effects, we estimate a fourth specification in which all of the independent variables are transformed into scaled decile ranks that range from zero to one. As a result, each coefficient in this specification measures the change in discretionary accruals when moving from the bottom decile to the top decile of the respective variable. ${ }^{15}$

Three of our findings are noteworthy. First, consistent with prior research (e.g., Bergstresser and Philippon, 2006), for two of the three measures of discretionary accruals, we find a positive relation between discretionary accruals and Delta ( $t$-stats of 2.97, 1.96, and 1.23, respectively). Second, across all three measures of discretionary accruals, we find a positive relation between discretionary accruals and Vega ( $t$-stats of 4.60, 4.22, and 4.28, respectively). Finally, across all three measures of discretionary accruals, when the incentive effects of portfolio delta and portfolio vega are considered simultaneously, the relation between Delta and

\footnotetext{
${ }^{15}$ We use the decile rank of each independent variable to ensure that all independent variables are of similar scale. This, in turn, allows us to meaningfully compare the relative economic significance of each variable. The ranked specification has the added advantage of being robust to both outliers and nonlinearities. Accordingly, this analysis also serves as a sensitivity check of our primary regression specification.
} 
discretionary accruals is statistically insignificant ( $t$-stats of $-0.83,-0.18$, and -0.82 , respectively) and the relation between Vega and discretionary accruals remains highly statistically significant ( $t$-stats of 4.40, 4.12, and 4.45, respectively). These results suggest that the incentive effects of portfolio vega on misreporting almost completely subsume the incentive effects of portfolio delta.

The economic effect of Vega on the magnitude of discretionary accruals is also large. In particular, when discretionary accruals are measured using the modified Jones model, the fourth column reports that moving from the bottom to the top decile of vega is associated with an increase in discretionary accruals of 4.93 (Vega coef 4.93, $t$-stat 4.00). ${ }^{16}$ By comparison, the average level of discretionary accruals is 12.21 (Table 2, Panel A), and only capital intensity has a greater economic impact on discretionary accruals (Capital coef $-6.33, t$-stat -8.44$)$. Although vega is less economically significant in the other two models of discretionary accruals (Vega coefs 1.77 and $1.70, t$-stats 3.30 and 3.65 , respectively), its effect is always among the most economically significant.

Panel B presents results after including firm fixed effects in the various regression specifications (for parsimony, we do not tabulate economic effects). By including firm fixed effects, the regression coefficients capture primarily within-firm, time-series variation rather than cross-sectional variation. Panel B shows that, considering the incentive effects of portfolio delta alone, the relation between Delta and discretionary accruals is not robust to including firm fixed effects. In particular, after controlling for firm fixed effects, regardless of the measure of discretionary accruals, we find an insignificant relation between Delta and discretionary accruals ( $t$-stats of 1.19, 1.28, and 1.34, respectively). These results indicate that variation in portfolio

\footnotetext{
${ }^{16}$ Recall that discretionary accruals are expressed as a percent of total assets (i.e., 4.93 corresponds to $4.93 \%$ of total assets).
} 
delta explains variation in discretionary accruals across firms, but not variation in discretionary accruals within firms. This suggests that the relation between portfolio delta and discretionary accruals may be confounded by unobserved, time-invariant firm characteristics that are correlated with both portfolio delta and discretionary accruals.

Regarding portfolio vega, the results in Panel B mirror those in Panel A. Specifically, we find that the coefficient on Vega is positive and highly significant across all specifications ( $t$-stats of $3.52,3.57$, and 3.45 , respectively) and that the coefficient on Vega remains highly statistically significant when the incentive effects of portfolio delta and portfolio vega are considered simultaneously ( $t$-stats of $3.42,3.35$, and 3.28 , respectively). These results suggest that variation in risk-taking incentives explains not only variation in discretionary accruals across firms, but also time-series variation in discretionary accruals within a firm.

\subsubsection{Risk-taking incentives and restatements}

Table 4 presents results from using accounting restatements to measure misreporting. Consistent with prior research (e.g., Burns and Kedia, 2006), we find a positive and highly significant relation between restatements and Delta ( $t$-stat of 3.52). We also find a positive and highly significant relation between restatements and Vega ( $t$-stat of 4.66). However, when the incentive effects of portfolio delta and portfolio vega are considered simultaneously in the third specification, the relation between Delta and restatements is not statistically significant ( $t$-stat of 1.31) and the relation between Vega and restatements remains highly statistically significant ( $t$ stat of 4.23). Consistent with our predictions, these results suggest that the incentive effects of portfolio vega on misreporting subsume the incentive effects of portfolio delta.

Finally, as with discretionary accruals, the fourth column presents results from estimating the probability of restatement as a function of the scaled decile ranks of the independent 
variables. We estimate this specification using a linear probability model (LPM) so that the coefficient on each independent variable represents the increase in the probability of a restatement when moving from the bottom decile to the top decile of the respective variable. In particular, the estimated coefficient on Vega of 0.03 ( $t$-stat 3.28) indicates that moving from the bottom to the top decile of vega increases the probability of restatement by 0.03 . By comparison, the unconditional probability of a restatement is 0.03 (Table 2, Panel A), and only return-onassets (ROA) has a greater economic impact on the probability of restatement (ROA coef -0.04 , t-stat -2.81).

Table 4, Panel B presents results from including firm fixed effects in our regression specifications. Panel B shows that, considering the incentive effects of portfolio delta alone, the relation between Delta and restatements is not robust to including firm fixed effects. Specifically, after including firm fixed effects, we find an insignificant relation between Delta and restatements ( $t$-stat of 1.46). This suggests that variation in Delta explains variation in the probability of a restatement across firms, but not variation in the probability of a restatement within a firm. This indicates that the relation between portfolio delta and restatements may be confounded by unobserved, time-invariant firm characteristics that are correlated with portfolio delta. Table 4 Panel B also shows that the coefficient on Vega is positive and highly significant ( $t$-stat of 4.17) and that the coefficient on Vega remains highly statistically significant when the incentive effects of portfolio delta and portfolio vega are considered simultaneously $(t$-stat of 3.90). These results suggest that variation in portfolio vega explains not only variation in the incidence of accounting restatements across firms, but also time-series variation in the incidence of accounting restatements within a firm.

\subsubsection{Risk-taking incentives and SEC Accounting and Auditing Enforcement Releases}


Table 5 presents results from using AAERs to measure misreporting. Considering the incentive effects of portfolio delta and portfolio vega separately, we find a positive and highly statistically significant relation between AAERs and Delta ( $t$-stat of 3.22) and AAERs and Vega ( $t$-stat of 3.14). However, when the incentive effects of portfolio delta and portfolio vega are considered simultaneously, the relation between Delta and restatements is statistically insignificant ( $t$-stat of 1.28) and the relation between Vega and restatements remains statistically significant ( $t$-stat of 2.65). These results suggest that the incentive effects of portfolio vega on misreporting subsume the incentive effects of portfolio delta. In addition, and similar to our previous results, the fourth column presents results from estimating the economic significance of the variables using a linear probability model (LPM) and the scaled decile ranks of the independent variables. We find that the economic magnitude of the effect of Vega on the probability of an AAER is large in both relative and absolute terms. Specifically, the estimated coefficient on Vega of 0.02 ( $t$-stat 2.40) indicates that moving from the bottom decile of vega to the top decile of vega increases the probability of an AAER by 0.02. By comparison, the unconditional probability of an AAER is 0.02 (Table 2, Panel A), and no other variable has a larger effect on the probability of misreporting. ${ }^{17}$

Table 5, Panel B presents results from including firm fixed effects in our regression specifications. Panel B shows that the relation between Delta and AAERs is robust to including firm fixed effects. After controlling for firm fixed effects, the coefficient on Delta is positive and statistically significant ( $t$-stat of 2.82). Likewise, the coefficient on Vega is also positive and statistically significant ( $t$-stat of 3.47). However, when the incentive effects of portfolio delta and

\footnotetext{
${ }^{17}$ Unlike our estimates of the ranked specifications for the previous measures of accounting manipulation, we find that Delta is positive and statistically significant. Although this positive and significant relation is not inconsistent with the theoretically ambiguous relationship, it should be interpreted with caution because of all the specifications estimated, it is the only specification in which we find a significant relation between Delta and misreporting when Vega is also included.
} 
portfolio vega are considered simultaneously, the coefficient on Delta is statistically insignificant ( $t$-stat of 1.18) and the coefficient on Vega remains statistically significant ( $t$-stat of 2.82$)$. These results suggests that variation in portfolio vega explains not only variation in the incidence of SEC enforcement releases across firms, but also time-series variation in the incidence of SEC enforcement releases within a firm.

\subsection{Matched-sample analysis}

Panel A of Table 6 reports results from comparing the incentives of misreporting firms to a size-and-industry matched-sample of non-misreporting firms. When restatements are used as the measure of misreporting, we find no difference in mean or median values of Delta across the two samples ( $p$-values of 0.37 and 0.87 , respectively), but that misreporting firms have significantly higher mean and median levels of Vega ( $p$-values of 0.001 and $<0.001$, respectively). When AAERs are used as the measure of misreporting, we again find no difference in mean or median values of Delta across the two samples ( $p$-values of 0.87 and 0.97 , respectively) and that misreporting firms have significantly higher mean and median levels of Vega ( $p$-values 0.02 and 0.04 for the difference in means and medians, respectively).

Collectively, and consistent with Erickson et al. (2006), Efendi et al. (2007), and Armstrong et al. (2010), we find no evidence of a relation between portfolio delta and misreporting using these matched-sample tests. However, we expand on these studies and additionally consider portfolio vega. In contrast to portfolio delta, we find strong evidence of a positive relation between risktaking incentives and misreporting.

Panel B reports results for the propensity-score matched-sample. Panel B presents the differences in mean and median values of variables used to estimate the propensity score, the observed level of risk-taking incentives, and measures of misreporting between the treatment and 
matched-sample. Consistent with propensity score matching resulting in covariate balance, and hence a successful match, we find a significant difference in the means across treatment and matched-samples for only one of 18 variables used to estimate the propensity score (CashComp, $p$-value $<0.001)$ and a significant difference in the median values for only three of the 18 variables (CashComp, Intangibles, and InterestCov, p-values 0.002, 0.002, and <0.001, respectively). ${ }^{18}$ Moreover, the absolute magnitudes of these mean and median differences are quite small. We interpret these results as suggesting that the probability distributions of the variables used to construct the matched-sample do not differ significantly across the two samples. Thus, the treatment and the matched-samples are very similar along many observed attributes including recent stock performance (i.e., Returns).

Consistent with the matching algorithm minimizing the difference in propensity score while maximizing the difference in Vega, we find highly significant differences in Vega across the two samples ( $p$-values $<0.001$ for both the difference in means and medians). The fact that the two samples are similar along so many dimensions, but have dissimilar portfolio vega, suggests that any variation in misreporting across the two samples is likely attributable to differences in portfolio vega rather than differences in other characteristics.

Unlike Armstrong et al. (2010), who use a propensity score matched-sample based on portfolio delta and find no evidence of a relation between portfolio delta and either restatements or AAERs, we form our matched-sample based on portfolio vega and find a positive relation between portfolio vega and discretionary accruals, restatements, and AAERs. Across all four measures of discretionary accruals, we find that both the mean and median level of Discretion for the treatment firms exceeds those of the matched firms ( $p$-values range from $<0.001$ to 0.02 ).

\footnotetext{
${ }^{18} \mathrm{We}$ are unable to attain successful matches for $5 \%$ of firms. Accordingly, the resulting sample is reduced from 20,445 to 19,418 firm-years.
} 
We also find that the probability that the average treatment firm restates is $50 \%$ higher than the average control firm and that this difference is highly statistically significant $(0.03$ versus 0.02 , $p$-value of 0.004). Similarly, we find that the probability that the average treatment firm is the subject of an AAER is $50 \%$ higher than the average control firm (0.02 versus $0.01, p$-value of 0.02). ${ }^{19}$ These results confirm the positive relation between Vega and misreporting documented in our regression tests. These results are also consistent with prior studies that find no evidence of a relation between Delta and misreporting in matched-samples (e.g., Erickson et al., 2006; Efendi et al., 2007; Armstrong et al., 2010). Importantly, the results from our matched-sample tests show that examining the relation between equity incentives and misreporting without considering risk-taking incentives can lead to the erroneous inference that equity incentives are unrelated to misreporting.

\subsection{Supplemental analyses}

\subsubsection{Incremental importance of the CEO's incentives}

Table 7 presents results from regressing our measures of misreporting on the equity incentives of both the CEO and the top management team. Consistent with our earlier results, when the CEO's portfolio delta and portfolio vega are considered simultaneously, we find no evidence of a relation between CEODelta and discretionary accruals, restatements, or AAERs ( $t$ stats of $0.13,1.14$, and 1.28 , respectively), and strong evidence of a positive relation between CEOVega and all three measures of misreporting ( $t$-stats of 4.66, 3.23, and 2.98, respectively). When we include both the CEO's equity incentives and those of the top management team in the specification, we find that the CEO's portfolio delta and portfolio vega are not incrementally associated with misreporting. Instead, we continue to find that the portfolio vega of the top

\footnotetext{
${ }^{19}$ Because Restatement and $A A E R$ are binary variables and have identical medians (i.e., zero), we cannot test for a difference in median.
} 
management team is positively associated with all three measures of misreporting ( $t$-stats of $3.35,3.54$, and 2.81, respectively). Because the top management team includes the CEO, these results indicate that the CEO's incentives are not incrementally associated with misreporting. This result is consistent with recent findings in the literature regarding the potential complicity of other members of the management team in financial misreporting (Jiang et al., 2010).

\subsubsection{Alternative measures of equity incentives}

To assess the robustness of our results to measurement choices, we repeat our tests using alternative measures of equity incentives that are common in the prior literature. Table 8, Panel A presents results from scaling portfolio delta and vega by either salary or total cash compensation. ${ }^{20}$ The results in Panel A show that (if anything) ScaledDelta is negatively related with misreporting ( $t$-stats range from -3.26 to -0.18$)$. In contrast, we find the coefficient on ScaledVega is positive and statistically significant across all specifications ( $t$-stats range from 2.07 to 4.38 ). These results suggest that the positive association between Vega and misreporting and the lack of an incremental association between Delta and misreporting are not sensitive to scale considerations.

Table 8, Panel B presents results from repeating our tests using five alternative measures of equity incentives that are common in the literature. Interestingly, and in contrast to our findings for Delta, we find that several of these alternative measures of equity incentives are incrementally related to misreporting. For example, we find that the amount of equity pay (EquityComp) and the intrinsic value of managers' option portfolios (Moneyness) are both positively related to restatements ( $t$-stats 2.98 and 2.05, respectively) and AAERs ( $t$-stats of 2.52 and 3.18, respectively). Importantly, the results in Panel B show that, controlling for Vega, the

\footnotetext{
${ }^{20}$ For the analysis in Table 8, we impose the additional requirement of non-missing values for all alternative measures. Since several alternative measures are only defined for variables where the scaler (e.g., salary) is nonzero, this requirement drops 19 firm-years from the sample (20,426 from 20,445 firm years).
} 
amount of options granted to the top management team during the year (Options) has an ambiguous association with misreporting. Specifically, Options is negatively related to discretionary accruals ( $t$-stat of -2.14$)$ but positively related to SEC actions ( $t$-stat of 2.07$)$. This is consistent with the notion that option grants alone do not encourage misreporting, but rather it is the specific terms or parameterization of the option grants that encourage misreporting. Finally, across all three measures of misreporting, we continue to find a positive relation between Vega and misreporting even after including these alternative measures ( $t$-stats of 4.88, 3.75, and 2.53 , respectively) and no relation between Delta and misreporting ( $t$-stats of $-0.61,1.20$, and 0.50 , respectively).

\subsubsection{Sources of vega}

Portfolio vega is a function of both the current stock price and features of the option grant (e.g., strike price). As a result, changes in stock price subsequent to the option grant may create similar variation in both vega and misreporting. For example, a firm may grant executives options that are in-the-money at the time of the grant (low vega), but after a subsequent drop in stock price, the options may be at-the-money (high vega). In this case, while vega may still provide incentives to misreport, variation in these incentives may be related to variation in subsequent performance rather than variation in the innate features of the option grant. While we control for current stock performance in our regression and matched-sample tests, we conduct two additional tests to examine whether the relation between vega and misreporting is coming from (a) the component of vega attributable to recent performance or (b) the component of vega attributable to features of the grant.

First, for each firm, we decompose vega into two components: the component correlated with recent performance (VegaPerf) and the component uncorrelated with recent performance 
(VegaNonPerf). ${ }^{21}$ Panel A of Table 9 reports results from repeating our tests using these two components of vega. We find modest evidence of a positive relation between the component of vega that is correlated with firm performance and discretionary accruals, restatements, and AAERs ( $t$-stats 2.87, 2.25, and 1.64, respectively), and strong evidence of a positive relation between the component of vega that is uncorrelated with firm performance and all three measures of misreporting ( $t$-stats $5.04,4.11$, and 2.02 , respectively). While variation in firm performance can induce variation in vega, variation in vega that is unrelated to recent performance appears to have incremental explanatory power for all three measures of misreporting.

Second, we decompose total portfolio vega into the vega from previously granted options (VegaOld) and the vega of new options granted during the year (VegaNew).

$$
\text { Vega }=\text { VegaOld }+ \text { VegaNew } .
$$

Since vega is calculated at the end of the fiscal year, we can further decompose the vega of new grants into vega on the day of the grant (GrntDtVegaNew), and the change in vega between the grant date and the end of the year (ChngVegaNew). ${ }^{22}$

$$
\text { Vega }=\text { VegaOld }+ \text { GrntDtVegaNew }+ \text { ChngVegaNew } .
$$

Because compensation disclosures prior to 2006 do not provide the grant date of previously granted options, we are only able to calculate "grant date vega" for new option grants. ${ }^{23}$

Decomposing the vega of new grants into grant date vega and the subsequent change in vega

\footnotetext{
${ }^{21}$ VegaPerf (VegaNonPerf) is the predicted value (residual) from a firm-specific regression of Vega on Returns. We require at least five years of data to estimate the regression, which reduces the sample to 18,405 firm-years.

${ }^{22}$ VegaNew is the natural logarithm of one plus the vega of option grants during the year, VegaOld is Vega minus VegaNew, GrntDtVegaNew is the natural logarithm of one plus the vega of new options granted during the year calculated on the grant date, and ChngVegaNew is VegaNew minus GrntDtVegaNew. As with all our incentive measures, the components of vegas are averaged across the top five executives.

${ }^{23}$ Approximately $95 \%$ of options are granted at-the-money in the Execucomp database.
} 
during the year allows us to separately identify the portion of vega attributable to features of the grant from the portion of vega attributable to post-grant stock performance.

Panel B of Table 9 reports results from repeating our tests using these four components of vega. We find a strong positive relation between the vega from new option grants and all three measures of misreporting ( $t$-stats 3.90, 4.61, and 2.97, respectively). Decomposing the vega from new options, we find a strong positive relation between grant date vega and all three measures of misreporting ( $t$-stats $3.87,4.63$, and 3.01, respectively), but no evidence of a relation between the change in vega over the year and any measure of misreporting ( $t$-stats $1.09,1.07$, and 1.57 , respectively). Collectively, these results suggest that the relation between vega and misreporting is driven by the component of vega attributable to features of the grant rather than the component of vega attributable to firm performance following the grant.

\subsubsection{The vega-delta incentive wedge}

Throughout our analyses, we find a positive relation between portfolio vega and various measures of misreporting, and that this relation generally subsumes the relation between portfolio delta and misreporting. To further explore the result that Vega tends to diminish the statistical significance of Delta, we conduct a supplemental analysis in which we identify specific observations that are most responsible for driving a "wedge" between the effect of Vega and Delta on misreporting. We conduct this analysis by calculating each observation's influence on the magnitude of the estimated coefficients on Vega and Delta. Similar to Belsley, Kuh, and Welsch (1980), we begin by defining DFBETA $_{\text {Vega }}\left(D_{F B E T A_{\text {Delta }}}\right)$ for a particular regression specification, as the change in coefficient on Vega (Delta) from including that firm-year in the regression. The difference between $D_{F B E T A_{\text {Vega }}}$ and $D F B E T A_{\text {Delta }}$ then measures the extent to 
which each observation accounts for the difference in the effect of Vega and Delta on

misreporting. We refer to this difference as the "vega-delta wedge."

Table 10 separately reports variable means for observations in the highest percentile of the vega-delta wedge and all other observations. ${ }^{24} \mathrm{~A}$ few notable patterns emerge from this table. First, across all measures of misreporting, the observations that are most responsible for the significant positive coefficient on Vega and the insignificant coefficient on Delta have much larger discretionary accruals, are more likely to restate their financial reports, and are more likely to have an SEC enforcement action brought against them. Second, these observations also generally tend to have larger vega (difference in Vega of $0.09,1.02$, and 1.00, respectively) and larger delta (difference in Delta $-0.04,0.20$, and 0.78, respectively). Importantly, while these observations do not have greater equity ownership (difference in Ownership of $0.18,-0.26$, and 0.06, respectively), a significantly greater percentage of their equity portfolio is comprised of options (difference in OptionEquityRatio of $0.07,0.18$, and 0.12 , respectively). Third, these observations also tend to (i) have greater investment opportunities (differences in $B M$ of $-0.03,-$ 0.04, and -0.07 , respectively), (ii) be younger (differences in FirmAge of $-4.08,-4.81$, and 3.25 , respectively), (iii) have lower return-on-assets (differences in $R O A$ of $-0.05,0.00$, and 0.03, respectively), (iv) be less capital intensive (differences in Capital of $-0.01,-0.10$, and 0.10 , respectively), (v) have higher cash flow volatility (differences in $\sigma C F O$ of $0.01,0.02$, and 0.01, respectively), and (vi) have higher sales volatility (differences in $\sigma$ Sales of $0.02,0.03$, and

\footnotetext{
${ }^{24}$ Results are similar if we consider observations in the top $5 \%$ or top $10 \%$ of the vega-delta wedge. The ten firms with the largest vega-delta wedge for discretionary accruals are Carmike Cinemas, Collective Brands, Covance, Lenox Group, Blockbuster, Westwood One, Barrick Gold, Time Warner, Price Communications, and CPI Corp. The ten firms with the largest vega-delta wedge for restatements are Applied Micro Circuits, Catalina Marketing, Sourcecop, Epiq Systems, Actel, Duquesne Light, Molex, Conagra Foods, Hain Celestial Group, and Altera. The ten firms with the largest vega-delta wedge for AAERs are Black Box, Conagra Foods, Delphi, Northwesterm, Hain Celestial, Qwest Communications, Tidewater, Impath, Diebold, and Bristow Group. There is minimal overlap in the top ten firms across the three measures of misreporting, which suggests a common set of firms is not driving our collective results, and that discretionary accruals, restatements, and SEC enforcement actions capture different dimensions, or types of misreporting.
} 
0.03 , respectively). These findings are consistent with prior research on settings where risktaking incentives are more prevalent (e.g., Guay, 1999).

\subsubsection{Ability to exit equity positions}

The degree to which equity portfolios provide managers with incentives to misreport may also depend on the extent to which managers expect to "cash out" of their equity portfolios prior to the detection of the misreporting (i.e., sell at an inflated stock price). In the extreme, if managers do not expect to be able to sell any of their equity holdings prior to detection (e.g., managers expect immediate detection), it is unlikely that their equity portfolios would provide them with a strong incentive to misreport because they would not expect to benefit from any increase in portfolio value. On the other hand, if managers do not expect to get caught, it is unclear when they would "cash out."

Prior studies suggest that managers at least partially cash out prior to detection. For example, Efendi et al. (2007) find that during years that are subsequently restated, CEOs' proceeds from option exercises are more than nine times higher than those of their counterparts at non-restating firms. In addition, Burns and Kedia (2006) find that option exercises by CEOs in years that are subsequently restated are negatively related to the subsequent price reaction when the restatement is announced. These findings suggest that executives partially divest their holdings before misreporting is detected, and that the magnitude of their divesture is related to the magnitude of the misreporting (as measured by the stock price reaction).

For our sample of restatements, we find that the time between misreporting and detection is, on average, 31.5 months (median of 26 months). These statistics suggest that the average executive who misreports and subsequently gets caught has time to (at least partially) "cash out" at inflated prices. Consistent with prior work, during the period for which financials are 
misreported, across all measures of misreporting (i.e., discretionary accruals, restatements, and AAERs), we find significantly higher levels of option exercise and equity sales at misreporting firms. Similar to Efendi et al. (2007), we find that during years that are subsequently restated, the average top five executive realizes proceeds from option exercises that are twice that of the average top five executive at non-restating firms. In untabulated analysis, we include contemporaneous equity sales and option exercise as an additional variable in our misreporting regressions, and across all measures of misreporting, we find a positive relation (statistically significant at the 5\% level for Discretion, $1 \%$ level for Restatement, and 10\% level for AAER).

\subsubsection{Selection on firm or executive characteristics}

As with most prior work on incentives, it is difficult to disentangle the effect induced by the contract's incentives and any effects due to innate executive characteristics (e.g., risk aversion). For example, prior work has attempted to relate executive characteristics (e.g., education, background, and degree of overconfidence) to various firm outcomes. In the specific context of financial misreporting, Schrand and Zeckman (2012) argue that overconfident managers are inherently more likely to commit fraud. In addition to being inherently more likely to commit fraud, it may also be the case that overconfident managers (or managers of some other particular characteristic) are more likely to select contracts that provide high risk-taking incentives. As a result, the relation between risk-taking incentives and misreporting may be confounded by these unobservable executive-specific characteristics.

We attempt to mitigate this concern in three ways. First, our primary analysis is based on the incentives of the top management team rather than the incentives of a particular executive. However, it may be the case that selection occurs at the team- or firm-level, such that certain firms attract top-level managers that both prefer equity-based pay and are more likely to 
misreport. Second, our primary regression specifications include firm fixed effects. This withinfirm research design makes it less likely that portfolio delta and vega are capturing some omitted firm-specific characteristic that is correlated with both risk-taking incentives and misreporting. Third, in untabulated analyses, we estimate our regression tests using only the incentives of the CEO, but also include CEO fixed effects. Across all specifications, we find that the positive relation between vega and misreporting is robust to including CEO fixed effects, and that the positive relation between portfolio delta and misreporting continues to be subsumed by portfolio vega. More importantly, this within-executive research design makes it less likely that delta and vega are capturing some omitted executive-specific characteristic that explains misreporting. Instead, these results suggest that holding the executive constant, temporal variation in risktaking incentives explains temporal variation in misreporting. Collectively, these results are consistent with risk-taking incentives directly affecting the likelihood of misreporting, and mitigate concerns that the positive relation between vega and misreporting is due to selection on unobservable firm- or executive-specific characteristics.

\section{Conclusion}

A large body of prior literature examines the relation between managerial equity incentives and financial misreporting but reports mixed results. This literature argues that a manager whose wealth is more sensitive to changes in stock price has a greater incentive to misreport. However, if managers are risk-averse and misreporting increases both equity values and equity risk, managers face a risk/return tradeoff when making a misreporting decision. In this case, the sensitivity of the manager's wealth to changes in stock price, or portfolio delta, will have two countervailing incentive effects: a positive "reward effect" and a negative "risk effect." 
In contrast, the sensitivity of the manager's equity portfolio to changes in risk, or portfolio vega, will have an unambiguously positive incentive effect. Accordingly, when managers are riskaverse, it is important to jointly consider both portfolio delta and portfolio vega when assessing the relation between equity incentives and misreporting.

We show that jointly considering both portfolio delta and portfolio vega substantially alters inferences reported in the literature. Specifically, we find inferences in studies reporting either a positive relation or no relation between portfolio delta and misreporting are not robust to controlling for vega. Using both regression and matching designs, and measuring misreporting using discretionary accruals, restatements, and SEC Accounting and Auditing Enforcement Releases, we find strong evidence of a positive relation between portfolio vega and misreporting and that the incentives provided by portfolio vega subsume those of portfolio delta. We continue to find a positive relation between vega and misreporting when we include firm fixed effects in our regression specifications and no incremental relation between delta and misreporting. This suggests that variation in risk-taking incentives explains not only variation in misreporting across firms, but also time-series variation in misreporting within a firm.

Our results suggest a more nuanced view of equity incentives as they relate to misreporting. By explicitly considering the role of risk-taking incentives on the decision to misreport, and simultaneously estimating the incentive effects of portfolio delta and vega, our results potentially reconcile the conflicting evidence reported in prior studies that focus exclusively on portfolio delta. The results suggest that equity portfolios provide managers with incentives to misreport not because they tie the manager's wealth to equity value, but because they tie the manager's wealth to equity risk. 


\section{Appendix A. \\ Variable definitions}

Dependent variables

Discretion The absolute value of discretionary accruals expressed as a percentage of total assets, calculated from one of three models of accruals. The models considered are (1) modified Jones (1991), (2) Dechow and Dichev (2002), and (3) McNichols (2002).

Restatement Equals one if financial results for that year were restated and zero otherwise. We consider only restatements related to fraud, misrepresentation, or an investigation by the SEC or PCAOB (e.g., Hennes et al., 2008).

$A A E R \quad$ Equals one if the SEC published an Accounting and Auditing Enforcement Release that identified accounting fraud or misrepresentation at the firm that year and zero otherwise.

$\underline{\text { Incentive variables }}$

CashComp Natural logarithm of one plus the average total cash compensation received by the top five executives during the year.

Delta Natural logarithm of one plus the average sensitivity of the top five executives' equity portfolio to a $1 \%$ change in stock price (e.g., Core and Guay, 2002).

Vega Natural logarithm of one plus the average sensitivity of the top five executives' equity portfolio to a 0.01 change in stock volatility (e.g., Core and Guay, 2002).

CEOComp Natural logarithm of one plus the total cash compensation received by the CEO during the year.

CEODelta Natural logarithm of one plus the sensitivity of the CEO's equity portfolio to a $1 \%$ change in stock price.

CEOVega Natural logarithm of one plus the sensitivity of the CEO's equity portfolio to a 0.01 change in volatility.

ScaledDelta Sensitivity of the executive's stock and option portfolio to a $1 \%$ change in stock price scaled by either salary or total cash compensation for the average top five officer (e.g., Bergstresser and Philippon, 2006; Efendi et al., 2007).

ScaledVega Sensitivity of the executive's stock and option portfolio to a 0.01 change in volatility scaled by either salary or total cash compensation for the average top five officer.

EquityComp Ratio of the value of stock and options grants to total pay for the average top five officer (e.g., Larcker et al., 2007).

Ownership Number of options, shares of restricted stock, and shares of unrestricted stock held by the average top five officer as a percent of shares outstanding (e.g., Cheng and Warfield, 2005).

Options Number of options granted to the average top five officer during the year as a percent of shares outstanding (e.g., Cheng and Farber, 2008).

Moneyness $\quad$ Value of in-the-money stock options scaled by salary for the average top five officers (e.g., Efendi et al., 2007).

Gamma Natural logarithm of one plus the average sensitivity of the top five executives' portfolio delta to changes in stock price, i.e., second derivative of the Black-Scholes value with respect to stock price (e.g., Burns and Kedia, 2006). 


\section{Appendix A. \\ Variable Definitions, (cont'd)}

Control variables

\begin{tabular}{|c|c|}
\hline Size & Natural logarithm of market value. \\
\hline$B M$ & Ratio of book value of equity to market value of equity. \\
\hline Leverage & Total liabilities divided by total assets. \\
\hline FirmAge & Number of years the firm appears on Compustat. \\
\hline Capital & Net plant, property, and equipment scaled by total assets. \\
\hline Intangibles & Ratio of research and development and advertising expense to sales. \\
\hline$R O A$ & Net income scaled by total assets. \\
\hline Return & Buy-and-hold returns over the year. \\
\hline$\sigma C F O$ & $\begin{array}{l}\text { Standard deviation of cash flows from operations over the prior ten years scaled } \\
\text { by total assets. }\end{array}$ \\
\hline oSales & Standard deviation of sales over the prior ten years scaled by total assets. \\
\hline Acquisition & $\begin{array}{l}\text { Indicator variable for whether an acquisition accounts for } 20 \% \text { or more } \\
\text { of total sales. }\end{array}$ \\
\hline Financing & $\begin{array}{l}\text { Amount raised from stock and debt issuances during the year scaled by total } \\
\text { assets. }\end{array}$ \\
\hline InterestCov & $\begin{array}{l}\text { Ratio of interest expense to net income. If net income for the year is negative or } \\
\text { interest expense is more than twice net income, Interest Cov is set to } 2 \text {. }\end{array}$ \\
\hline SalesGrowth & Change in sales scaled by prior-period sales. \\
\hline Inventory & Inventory scaled by total assets. \\
\hline Receivables & Accounts receivable scaled by total assets. \\
\hline
\end{tabular}

Dependent variables are measured at the end of year $t$, and incentive and control variables are measured at the end of year $t-1$. 


\section{References}

Armstrong, C., Jagolinzer, A., Larcker, D., 2010. Chief executive officer equity incentives and accounting irregularities. Journal of Accounting Research 48, 225-271.

Armstrong, C., Vashishtha, R., 2012. Executive stock options, differential risk-taking incentives, and firm value. Journal of Financial Economics 104, 70-88.

Bardos, K., Golec, J., Harding, J., 2011. Do investors see through mistakes in reported earnings? Journal of Financial and Quantitative Analysis 46, 1917-1946.

Belsley, D. A., Kuh, E., and Welsch. R. E., 1980. Regression Diagnostics. Wiley, New York.

Bergstresser, D., Philippon, T., 2006. CEO incentives and earnings management. Journal of Financial Economics 80, 511-529.

Bhattacharya, N., Desai, H., Venkataraman, K., 2012. Does earnings quality affect information asymmetry? Evidence from trading costs. Contemporary Accounting Research, forthcoming.

Burns, N., Kedia, S., 2006. The impact of performance-based compensation on misreporting. Journal of Financial Economics 79, 35-67.

Carpenter, J., 2000. Does option compensation increase managerial risk appetite? Journal of Finance 55, 2311-2331.

Chava, S., Purnanandam, A., 2010. CEOs versus CFOs: incentives and corporate policies. Journal of Financial Economics 97, 263-278.

Cheng, Q., Farber, D., 2008. Earnings restatements, changes in CEO compensation, and firm performance. The Accounting Review 83, 1217-1250.

Cheng, Q., Warfield, T.D., 2005. Equity incentives and earnings management. The Accounting Review 80, 441-476.

Coles, J., Daniel, N., Naveen, L., 2006. Managerial incentives and risk-taking. Journal of Financial Economics 79, 431-468.

Core, J., Guay, W., 2002. Estimating the value of employee stock option portfolios and their sensitivities to price and volatility. Journal of Accounting Research 40, 613-630.

Cornett, M., Marcus, A., Tehranian, H., 2008. Corporate governance and pay-for-performance: the impact of earnings management. Journal of Financial Economics 87, 357-373.

Dechow, P., Dichev, I., 2002. The quality of accruals and earnings: the role of accrual estimation errors. The Accounting Review 77, 35-59.

Dechow, P., Sloan, R., Sweeney, A., 1996. Causes and consequences of earnings manipulations: an analysis of firms subject to enforcement actions by the SEC. Contemporary Accounting Research 13, 1-36.

Dechow, P., Ge, W., Larson, C., Sloan, R., 2011. Predicting material accounting restatements. Contemporary Accounting Research 28, 17-82.

Efendi, J., Srivastava, A., Swanson, E., 2007. Why do corporate managers misstate financial statements? The role of option compensation and other factors. Journal of Financial Economics 85, 667-708.

Erickson, M., Hanlon, M., Maydew, E., 2006. Is there a link between executive equity incentives and accounting fraud? Journal of Accounting Research 44, 113-143.

Feng, M., Ge, W., Luo, S., Shevlin, T., 2011. Why do CFOs become involved in material accounting manipulations? Journal of Accounting and Economics 51, 21-36. 
Feroz, E., Park, K., Pastena, V., 1991. The financial and market effects of the SEC's Accounting and Auditing Enforcement releases. Journal of Accounting Research 29, 107-142.

Guay, W., 1999. The sensitivity of CEO wealth to equity risk: an analysis of the magnitude and determinants. Journal of Accounting and Economics 53, 43-71.

Hennes, K., Leone, A., Miller, B., 2008. The importance of distinguishing errors from irregularities in restatement research: the case of restatements and $\mathrm{CEO} / \mathrm{CFO}$ turnover. The Accounting Review 83, 1487-1519.

Jiang, J., Petroni, K., Wang, I., 2010. CFOs and CEOs: who have the most influence on earnings management? Journal of Financial Economics 96, 513-526.

Jones, J., 1991. Earnings management during import relief investigation. Journal of Accounting Research 29, 193-228.

Karpoff, J., Lee, S., Martin, G., 2008a. The cost to firms of cooking the books. Journal of Financial and Quantitative Analysis 43, 581-612.

Karpoff, J., Lee, S., Martin, G., 2008b. The consequences to managers for financial misrepresentation. Journal of Financial Economics 88, 193-215.

Kravet, T., Shevlin, T., 2010. Accounting restatements and information risk. Review of Accounting Studies 15, 264-294.

Lambert, R., Larcker, D., Verrecchia, R., 1991. Portfolio considerations in valuing executive compensation. Journal of Accounting Research 29, 129-149.

Larcker, D., Richardson, S., Tuna, I., 2007. Corporate governance, accounting outcomes, and organizational performance. The Accounting Review 82, 963-1008.

Lewellen, K., 2006. Financing decisions when managers are risk averse. Journal of Financial Economics 82, 551-589.

Low, A., 2009. Managerial risk-taking behavior and equity-based compensation. Journal of Financial Economics 92, 470-490.

McNichols, M., 2002. Discussion of the quality of accruals and earnings: the role of accrual estimation errors. The Accounting Review 77, 61-69.

Palmrose, Z., Richardson, V., Scholz, M., 2004. Determinants of market reactions to restatement announcements. Journal of Accounting and Economics 37, 59-89.

Rosenbaum, P., 2002. Observational Studies, Second ed. Springer-Verlag, Berlin.

Ross, S., 2004. Compensation, incentives, and the duality of risk aversion and riskiness. Journal of Finance 59, 207-225.

Schrand, C., Zechman, S., 2012. Executive overconfidence and the slippery slope to financial misreporting. Journal of Accounting and Economics 53, 311-329.

Smith, C., Stulz, R., 1985. The determinants of firms' hedging policies. Journal of Financial and Quantitive Analysis 20, 391-405. 


\section{Table 1}

Summary of prior literature on equity incentives and misreporting

This table categorizes prior studies on the relation between equity incentives and misreporting. Studies are categorized based on the primary measure of equity incentives, the measure of misreporting, the findings, and the type of research design. To be included in the table, the study's primary focus must be on the relation between equity incentives and misreporting and the study must have been published in the Journal of Finance, Journal of Financial Economics, Review of Financial Studies, Accounting Review, Journal of Accounting and Economics, or Journal of Accounting Research. $\delta$ refers to the sensitivity of the CEO's stock and option portfolio to a $1 \%$ change in stock price (e.g., Core and Guay, 2002), Ownership is the number of options, shares of restricted stock, and shares of unrestricted stock held by the executive as a percent of shares outstanding, Options is the number of options granted to the executive during the year as a percent of shares outstanding, Moneyness is the value of in-the-money stock options scaled by salary, and EquityComp is the value of stock and option grants during the year scaled by total pay. Discretionary accruals refers to unsigned discretionary accruals, Restatements refers to whether financial results were restated for any reason, and AAER refers to whether an SEC Accounting and Auditing Enforcement Release identified accounting fraud or misrepresentation at the firm. Regression refers to an analysis of an unmatched-sample exclusively. Matching refers to an analysis of a matched-sample.

\begin{tabular}{lllll}
\hline Paper & Primary measure of incentives & Measure of misreporting & Finding & Research design \\
\hline Cheng and Warfield (2005) & Ownership & Discretion & Positive relation & Regression \\
Bergstresser and Philippon (2006) & $\delta$ & Discretion & Positive relation & Regression \\
Burns and Kedia (2006) & $\delta$ & Restatement & Positive relation & Regression \\
Erickson et al. (2006) & $\delta$ & AAER & No relation & Matching \\
Efendi et al. (2007) & Moneyness & Restatements & Positive relation & Matching \\
Larcker et al. (2007) & EquityComp & Discretion, Restatements & No relation & Regression \\
Cheng and Farber (2008) & Options & Restatements & Positive relation & Regression \\
Cornett et al. (2008) & EquityComp & Discretion & Positive relation & Regression \\
Armstrong et al. (2010) & $\delta$ & Litigation, Restatements, AAERs & No relation & Matching \\
Jiang et al. (2010) & $\delta$ & Discretion & No relation CEO Regression & Positive CFO
\end{tabular}




\section{Table 2}

Descriptive statistics

This table presents descriptive statistics for firms in our sample. Our sample is constructed from the intersection of Execucomp (compensation), CRSP/Compustat (accounting and stock price data), AuditAnalytics (data on restatements), and the Center for Financial Reporting and Management (data on SEC Accounting and Auditing Enforcement Releases) for the time period 1992 to 2009 and covers a total of 20,445 firm-years (2,446 firms). Panel A reports descriptive statistics for measures of misreporting. Panel B reports descriptive statistics for selected firm characteristics. Panel C reports the distribution of the incentive variables used in our analysis. Panel D compares the mean and median values of incentive variables for the full sample to those of the sample of firms who restated their financials (Restatement=1) and were subject to an SEC Accounting and Auditing Enforcement Release $(A A E R=1)$. $p$-values test for a difference in means (medians) between the full sample and the restatement sample, and the full sample and the AAER sample. All variables are as defined in Appendix A.

\section{Panel A: Measures of misreporting}

\begin{tabular}{lccccc}
\hline Variable & Mean & Std & 25th & Median & 75th \\
\hline $\begin{array}{l}\text { Discretion } \\
\text { (Modified Jones) }\end{array}$ & 12.21 & 12.92 & 3.10 & 7.86 & 17.46 \\
$\begin{array}{l}\text { Discretion } \\
\text { (Dechow and Dichev) }\end{array}$ & 7.76 & 8.76 & 2.02 & 4.84 & 10.25 \\
$\begin{array}{l}\text { Discretion } \\
\text { (McNichols) }\end{array}$ & 7.74 & 8.91 & 1.97 & 4.69 & 10.10 \\
Restatement & 0.03 & 0.16 & 0.00 & 0.00 & 0.00 \\
AAER & 0.02 & 0.13 & 0.00 & 0.00 & 0.00
\end{tabular}

Panel B: Firm characteristics

\begin{tabular}{|c|c|c|c|c|c|}
\hline Variable & Mean & Std & 25 th & Median & 75 th \\
\hline Size & 7.27 & 1.57 & 6.18 & 7.14 & 8.28 \\
\hline$B M$ & 0.50 & 0.43 & 0.25 & 0.42 & 0.63 \\
\hline Leverage & 0.52 & 0.21 & 0.37 & 0.53 & 0.66 \\
\hline FirmAge & 26.08 & 16.41 & 11.00 & 22.00 & 42.00 \\
\hline$R O A$ & 0.04 & 0.12 & 0.02 & 0.05 & 0.09 \\
\hline Returns & 0.14 & 0.57 & -0.17 & 0.08 & 0.34 \\
\hline Capital & 0.32 & 0.23 & 0.13 & 0.26 & 0.47 \\
\hline Intangibles & 0.06 & 0.14 & 0.00 & 0.01 & 0.06 \\
\hline$\sigma C F O$ & 0.06 & 0.05 & 0.03 & 0.05 & 0.07 \\
\hline oSales & 0.22 & 0.18 & 0.10 & 0.16 & 0.27 \\
\hline Financing & 0.11 & 0.17 & 0.01 & 0.04 & 0.13 \\
\hline Acquisition & 0.04 & 0.20 & 0.00 & 0.00 & 0.00 \\
\hline InterestCov & 0.67 & 0.76 & 0.07 & 0.30 & 1.14 \\
\hline SalesGrowth & 0.14 & 0.31 & 0.01 & 0.09 & 0.21 \\
\hline Inventory & 0.12 & 0.12 & 0.02 & 0.09 & 0.17 \\
\hline Receivables & 0.15 & 0.10 & 0.07 & 0.13 & 0.20 \\
\hline
\end{tabular}


Table 2

Descriptive statistics (cont'd)

Panel C: Incentives variables

\begin{tabular}{lccccc}
\hline Variable & Mean & Std & 25 th & Median & 75 th \\
\hline CashComp & 6.29 & 0.59 & 5.86 & 6.25 & 6.66 \\
Delta & 4.46 & 1.44 & 3.51 & 4.44 & 5.41 \\
Vega & 2.96 & 1.37 & 2.06 & 2.98 & 3.89 \\
CEOCashComp & 6.76 & 0.77 & 6.29 & 6.75 & 7.23 \\
CEODelta & 5.24 & 1.67 & 4.22 & 5.25 & 6.30 \\
CEOVega & 3.46 & 1.72 & 2.49 & 3.65 & 4.65 \\
EquityComp & 0.43 & 0.39 & 0.18 & 0.37 & 0.59 \\
Ownership & 1.34 & 1.80 & 0.30 & 0.70 & 1.51 \\
Options & 0.11 & 0.17 & 0.01 & 0.06 & 0.14 \\
Moneyness & 9.97 & 28.94 & 0.49 & 2.74 & 8.99 \\
Gamma & 1.91 & 1.19 & 1.05 & 1.78 & 2.63
\end{tabular}

Panel D: Differences in incentives

\begin{tabular}{|c|c|c|c|c|c|c|c|c|c|c|}
\hline \multirow[b]{2}{*}{ Variable } & \multicolumn{2}{|c|}{$\begin{array}{l}\text { Full Sample } \\
(\mathrm{N}=20,445)\end{array}$} & \multicolumn{4}{|c|}{$\begin{array}{c}\text { Restatement Sample } \\
\text { (Restatement }=1, \mathrm{~N}=568)\end{array}$} & \multicolumn{4}{|c|}{$\begin{array}{c}\text { AAER Sample } \\
(A A E R=1, \mathrm{~N}=361)\end{array}$} \\
\hline & Mean & Median & Mean & $p$ & Median & $p$ & Mean & $p$ & Median & $p$ \\
\hline CashComp & 6.29 & 6.25 & 6.43 & $<0.01$ & 6.38 & $<0.01$ & 6.54 & $<0.01$ & 6.46 & $<0.01$ \\
\hline Delta & 4.46 & 4.44 & 4.96 & $<0.01$ & 4.85 & $<0.01$ & 5.32 & $<0.01$ & 5.20 & $<0.01$ \\
\hline Vega & 2.96 & 2.98 & 3.59 & $<0.01$ & 3.58 & $<0.01$ & 3.81 & $<0.01$ & 3.82 & $<0.01$ \\
\hline CEOCash Comp & 6.76 & 6.75 & 6.87 & $<0.01$ & 6.85 & $<0.01$ & 7.03 & $<0.01$ & 7.01 & $<0.01$ \\
\hline CEODelta & 5.24 & 5.25 & 5.75 & $<0.01$ & 5.74 & $<0.01$ & 6.21 & $<0.01$ & 6.08 & $<0.01$ \\
\hline CEOVega & 3.46 & 3.65 & 4.15 & $<0.01$ & 4.29 & $<0.01$ & 4.31 & $<0.01$ & 4.48 & $<0.01$ \\
\hline Equity Cотр & 0.43 & 0.37 & 0.63 & $<0.01$ & 0.53 & $<0.01$ & 0.70 & $<0.01$ & 0.58 & $<0.01$ \\
\hline Ownership & 1.34 & 0.70 & 1.31 & 0.66 & 0.94 & $<0.01$ & 1.35 & 0.86 & 0.82 & 0.05 \\
\hline Options & 0.11 & 0.06 & 0.15 & $<0.01$ & 0.09 & $<0.01$ & 0.16 & $<0.01$ & 0.08 & $<0.01$ \\
\hline Moneyness & 9.97 & 2.74 & 23.93 & $<0.01$ & 7.17 & $<0.01$ & 33.23 & $<0.01$ & 10.52 & $<0.01$ \\
\hline Gamma & 1.91 & 1.78 & 2.05 & $<0.01$ & 1.93 & $<0.01$ & 2.18 & $<0.01$ & 1.97 & $<0.01$ \\
\hline
\end{tabular}


Table 3

Risk-taking incentives and discretionary accruals

This table presents results from estimating discretionary accruals (Discretion) as a function of equity incentives and control variables. Panel A presents results from a pooled ordinary least squares (OLS) regression, and Panel B presents results including firm fixed effects. All variables are as defined in Appendix A. $t$-statistics appear in parentheses and are based on standard errors clustered by firm and year. ${ }^{* * *}{ }^{* *}$, and ${ }^{*}$ denote statistical significance at the $0.01,0.05$, and 0.10 levels (two-tail), respectively. Sample includes 20,445 firm-years. Sample descriptive characteristics are found in Table 2.

Panel A: Pooled regression

\begin{tabular}{|c|c|c|c|c|c|c|c|c|c|c|c|c|}
\hline \multirow[b]{2}{*}{ Variable } & \multicolumn{4}{|c|}{ Modified Jones (1991) } & \multicolumn{4}{|c|}{ Dechow and Dichev (2002) } & \multicolumn{4}{|c|}{ McNichols (2002) } \\
\hline & $\begin{array}{c}(1) \\
\text { OLS }\end{array}$ & $\begin{array}{c}(2) \\
\text { OLS } \\
\end{array}$ & $\begin{array}{c}(3) \\
\text { OLS }\end{array}$ & $\begin{array}{c}(4) \\
\text { Ranks } \\
\end{array}$ & $\begin{array}{c}(1) \\
\text { OLS }\end{array}$ & $\begin{array}{c}(2) \\
\text { OLS } \\
\end{array}$ & $\begin{array}{c}(3) \\
\text { OLS }\end{array}$ & $\begin{array}{c}(4) \\
\text { Ranks } \\
\end{array}$ & $\begin{array}{c}(1) \\
\text { OLS }\end{array}$ & $\begin{array}{c}(2) \\
\text { OLS } \\
\end{array}$ & $\begin{array}{c}(3) \\
\text { OLS }\end{array}$ & $\begin{array}{c}(4) \\
\text { Ranks } \\
\end{array}$ \\
\hline \multicolumn{13}{|c|}{ Incentive variables } \\
\hline CashComp & $\begin{array}{l}0.85^{*} \\
(1.78)\end{array}$ & $\begin{array}{c}0.15 \\
(0.39)\end{array}$ & $\begin{array}{c}0.19 \\
(0.48)\end{array}$ & $\begin{array}{c}0.69 \\
(0.94)\end{array}$ & $\begin{array}{c}0.29 \\
(1.05)\end{array}$ & $\begin{array}{c}0.02 \\
(0.10)\end{array}$ & $\begin{array}{c}0.03 \\
(0.12)\end{array}$ & $\begin{array}{c}0.10 \\
(0.27)\end{array}$ & $\begin{array}{c}0.29 \\
(1.05)\end{array}$ & $\begin{array}{c}0.02 \\
(0.07)\end{array}$ & $\begin{array}{c}0.03 \\
(0.12)\end{array}$ & $\begin{array}{c}0.15 \\
(0.37)\end{array}$ \\
\hline Delta & $\begin{array}{l}0.28^{* * * *} \\
(2.97)\end{array}$ & & $\begin{array}{c}-0.14 \\
(-0.83)\end{array}$ & $\begin{array}{c}-0.05 \\
(-0.06)\end{array}$ & $\begin{array}{l}0.13^{* * *} \\
(1.96)\end{array}$ & & $\begin{array}{c}-0.01 \\
(-0.18)\end{array}$ & $\begin{array}{c}-0.40 \\
(-1.05)\end{array}$ & $\begin{array}{c}0.09 \\
(1.23)\end{array}$ & . & $\begin{array}{c}-0.05 \\
(-0.82)\end{array}$ & $\begin{array}{l}-0.48 \\
(-1.36)\end{array}$ \\
\hline Vega & . & $\begin{array}{l}1.31^{* * * *} \\
(4.60)\end{array}$ & $\begin{array}{l}1.35^{* * * *} \\
(4.40)\end{array}$ & $\begin{array}{l}4.93^{* * * *} \\
(4.00)\end{array}$ & . & $\begin{array}{l}0.50^{* * * *} \\
(4.22)\end{array}$ & $\begin{array}{l}0.50^{* * * *} \\
(4.12)\end{array}$ & $\begin{array}{l}1.77^{* * * *} \\
(3.30)\end{array}$ & . & $\begin{array}{l}0.49^{* * * *} \\
(4.28)\end{array}$ & $\begin{array}{l}0.50^{* * *} \\
(4.45)\end{array}$ & $\begin{array}{l}1.70^{* * * *} \\
(3.65)\end{array}$ \\
\hline \multicolumn{13}{|c|}{ Control variables } \\
\hline Size & $\begin{array}{c}0.09 \\
(0.51)\end{array}$ & $\begin{array}{l}-0.36^{*} \\
(-1.66)\end{array}$ & $\begin{array}{c}-0.32 \\
(-1.61)\end{array}$ & $\begin{array}{l}-2.19^{* *} \\
(-2.36)\end{array}$ & $\begin{array}{c}0.10 \\
(1.09)\end{array}$ & $\begin{array}{c}-0.05 \\
(-0.52)\end{array}$ & $\begin{array}{c}-0.05 \\
(-0.48)\end{array}$ & $\begin{array}{c}-0.55 \\
(-1.09)\end{array}$ & $\begin{array}{c}0.12 \\
(1.10)\end{array}$ & $\begin{array}{c}-0.05 \\
(-0.48)\end{array}$ & $\begin{array}{c}-0.03 \\
(-0.28)\end{array}$ & $\begin{array}{c}-0.50 \\
(-0.99)\end{array}$ \\
\hline$B M$ & $\begin{array}{c}-0.52 \\
(-1.12)\end{array}$ & $\begin{array}{c}-0.64 \\
(-1.57)\end{array}$ & $\begin{array}{l}-0.70^{*} \\
(-1.66)\end{array}$ & $\begin{array}{c}-2.41^{* * * *} \\
(-2.98)\end{array}$ & $\begin{array}{c}-0.12 \\
(-0.45)\end{array}$ & $\begin{array}{c}-0.17 \\
(-0.65)\end{array}$ & $\begin{array}{c}-0.18 \\
(-0.65)\end{array}$ & $\begin{array}{c}-1.86^{* * *} \\
(-4.59)\end{array}$ & $\begin{array}{c}-0.38 \\
(-1.29)\end{array}$ & $\begin{array}{c}-0.43 \\
(-1.49)\end{array}$ & $\begin{array}{c}-0.45 \\
(-1.52)\end{array}$ & $\begin{array}{l}-2.16^{* * *} \\
(-5.12)\end{array}$ \\
\hline Leverage & $\begin{array}{l}-1.68^{*} \\
(-1.85)\end{array}$ & $\begin{array}{l}-1.94^{* * *} \\
(-2.19)\end{array}$ & $\begin{array}{l}-2.07^{* *} \\
(-2.38)\end{array}$ & $\begin{array}{c}-2.03^{* * * *} \\
(-3.28)\end{array}$ & $\begin{array}{c}-1.60^{* * *} \\
(-2.58)\end{array}$ & $\begin{array}{c}-1.42^{* * *} \\
(-2.74)\end{array}$ & $\begin{array}{c}-1.43^{* * *} \\
(-2.78)\end{array}$ & $\begin{array}{c}-1.28^{* * *} \\
(-4.20)\end{array}$ & $\begin{array}{l}-1.23^{* * *} \\
(-2.46)\end{array}$ & $\begin{array}{c}-1.30 \text { *** } \\
(-2.69)\end{array}$ & $\begin{array}{c}-1.34^{* * * *} \\
(-2.72)\end{array}$ & $\begin{array}{l}-1.18^{* * * *} \\
(-4.22)\end{array}$ \\
\hline FirmAge & $\begin{array}{c}-0.01 \\
(-1.17)\end{array}$ & $\begin{array}{c}-0.01 \\
(-0.83)\end{array}$ & $\begin{array}{c}-0.01 \\
(-1.01)\end{array}$ & $\begin{array}{c}0.41 \\
(0.84)\end{array}$ & $\begin{array}{c}-0.03^{* * * *} \\
(-4.44)\end{array}$ & $\begin{array}{c}-0.03^{* * *} \\
(-4.33)\end{array}$ & $\begin{array}{c}-0.03^{* * *} \\
(-4.31)\end{array}$ & $\begin{array}{l}-0.78^{* * *} \\
(-2.48)\end{array}$ & $\begin{array}{c}-0.03^{* * *} \\
(-4.24)\end{array}$ & $\begin{array}{c}-0.02^{* * *} \\
(-4.10)\end{array}$ & $\begin{array}{c}-0.02^{* * *} \\
(-4.18)\end{array}$ & $\begin{array}{l}-0.66^{* *} \\
(-1.99)\end{array}$ \\
\hline$R O A$ & $\begin{array}{c}-11.20^{* * * *} \\
(-4.59)\end{array}$ & $\begin{array}{c}-10.43^{* * *} \\
(-4.80)\end{array}$ & $\begin{array}{c}-10.34^{* * *} \\
(-4.77)\end{array}$ & $\begin{array}{l}-3.63^{* * * *} \\
(-4.25)\end{array}$ & $\begin{array}{l}-6.89^{* * *} \\
(-5.11)\end{array}$ & $\begin{array}{l}-6.61^{* * * *} \\
(-5.00)\end{array}$ & $\begin{array}{l}-6.60^{* * * *} \\
(-4.97)\end{array}$ & $\begin{array}{l}-1.40^{* * *} \\
(-4.10)\end{array}$ & $\begin{array}{l}-8.56^{* * *} \\
(-5.90)\end{array}$ & $\begin{array}{l}-8.25^{* * *} \\
(-6.20)\end{array}$ & $\begin{array}{l}-8.21^{* * *} \\
(-6.13)\end{array}$ & $\begin{array}{l}-1.77^{* * *} \\
(-6.27)\end{array}$ \\
\hline Returns & $\begin{array}{c}-0.36 \\
(-0.53)\end{array}$ & $\begin{array}{l}-0.01 \\
(-0.01)\end{array}$ & $\begin{array}{c}0.03 \\
(0.04)\end{array}$ & $\begin{array}{c}-1.23 \\
(-0.95)\end{array}$ & $\begin{array}{c}0.10 \\
(0.35)\end{array}$ & $\begin{array}{c}0.23 \\
(0.89)\end{array}$ & $\begin{array}{c}0.24 \\
(0.91)\end{array}$ & $\begin{array}{c}-0.73 \\
(-1.55)\end{array}$ & $\begin{array}{c}-0.01 \\
(-0.02)\end{array}$ & $\begin{array}{c}0.12 \\
(0.53)\end{array}$ & $\begin{array}{c}0.13 \\
(0.59)\end{array}$ & $\begin{array}{l}-0.89^{* *} \\
(-2.07)\end{array}$ \\
\hline Capital & $\begin{array}{c}-10.59^{* * *} \\
(-12.26)\end{array}$ & $\begin{array}{l}-9.80^{* * *} \\
(-10.16)\end{array}$ & $\begin{array}{l}-9.85^{* * *} \\
(-10.45)\end{array}$ & $\begin{array}{l}-6.33^{* * *} \\
(-8.44)\end{array}$ & $\begin{array}{l}-2.19^{\text {*** }} \\
(-3.77)\end{array}$ & $\begin{array}{l}-1.89^{* * * *} \\
(-3.32)\end{array}$ & $\begin{array}{l}-1.90^{* * * *} \\
(-3.39)\end{array}$ & $\begin{array}{l}-1.17^{* * * *} \\
(-2.90)\end{array}$ & $\begin{array}{l}-2.70^{* * *} \\
(-6.16)\end{array}$ & $\begin{array}{l}-2.41^{* * * *} \\
(-5.88)\end{array}$ & $\begin{array}{l}-2.43^{\text {**** }} \\
(-5.99)\end{array}$ & $\begin{array}{l}-1.56^{* * * *} \\
(-4.50)\end{array}$ \\
\hline Intangibles & $\begin{array}{c}-0.43 \\
(-0.21)\end{array}$ & $\begin{array}{l}-1.25 \\
(-0.66)\end{array}$ & $\begin{array}{c}-1.27 \\
(-0.67)\end{array}$ & $\begin{array}{l}1.27^{*} \\
(1.77)\end{array}$ & $\begin{array}{c}2.05 \\
(1.30)\end{array}$ & $\begin{array}{c}1.77 \\
(1.15)\end{array}$ & $\begin{array}{c}1.77 \\
(1.15)\end{array}$ & $\begin{array}{l}0.83^{* *} \\
(2.53)\end{array}$ & $\begin{array}{c}1.08 \\
(0.69)\end{array}$ & $\begin{array}{c}0.71 \\
(0.47)\end{array}$ & $\begin{array}{c}0.71 \\
(0.47)\end{array}$ & $\begin{array}{l}0.89^{* * * *} \\
(2.77)\end{array}$ \\
\hline$\sigma C F O$ & $\begin{array}{c}16.26^{* * * *} \\
(3.57)\end{array}$ & $\begin{array}{c}14.86^{* * *} \\
(3.43)\end{array}$ & $\begin{array}{c}14.74^{* * * *} \\
(3.40)\end{array}$ & $\begin{array}{l}2.94^{* * * *} \\
(5.60)\end{array}$ & $\begin{array}{c}23.99^{* * * *} \\
(7.49)\end{array}$ & $\begin{array}{c}23.44^{* * * *} \\
(7.49)\end{array}$ & $\begin{array}{c}23.43^{* * * *} \\
(7.48)\end{array}$ & $\begin{array}{l}4.08^{* * * *} \\
(12.65)\end{array}$ & $\begin{array}{c}26.08^{* * *} \\
(9.05)\end{array}$ & $\begin{array}{c}25.68^{* * * *} \\
(9.18)\end{array}$ & $\begin{array}{c}25.62^{* * * *} \\
(9.15)\end{array}$ & $\begin{array}{l}4.32^{* * * *} \\
(12.62)\end{array}$ \\
\hline бSales & $\begin{array}{c}-0.37 \\
(-0.39) \\
\end{array}$ & $\begin{array}{c}-0.39 \\
(-0.40) \\
\end{array}$ & $\begin{array}{c}-0.35 \\
(-0.36) \\
\end{array}$ & $\begin{array}{c}-0.64 \\
(-0.98) \\
\end{array}$ & $\begin{array}{c}-0.25 \\
(-0.49) \\
\end{array}$ & $\begin{array}{c}-0.21 \\
(-0.42)\end{array}$ & $\begin{array}{c}-0.21 \\
(-0.41)\end{array}$ & $\begin{array}{c}-0.42 \\
(-1.35)\end{array}$ & $\begin{array}{c}0.08 \\
(0.15)\end{array}$ & $\begin{array}{c}0.07 \\
(0.15)\end{array}$ & $\begin{array}{c}0.10 \\
(0.20)\end{array}$ & $\begin{array}{c}-0.43 \\
(-1.39)\end{array}$ \\
\hline$R^{2}(\%)$ & 10.04 & 11.39 & 11.40 & 11.60 & 9.67 & 10.15 & 10.15 & 9.00 & 10.63 & 11.05 & 11.06 & 9.95 \\
\hline
\end{tabular}


Table 3

Risk-Taking incentives and discretionary accruals (cont'd)

Panel B: Firm fixed effects

\begin{tabular}{|c|c|c|c|c|c|c|c|c|c|}
\hline \multirow[b]{2}{*}{ Variable } & \multicolumn{3}{|c|}{ Modified Jones (1991) } & \multicolumn{3}{|c|}{ Dechow and Dichev (2002) } & \multicolumn{3}{|c|}{ McNichols (2002) } \\
\hline & $\begin{array}{c}(1) \\
\text { Fixed } \\
\text { effects }\end{array}$ & $\begin{array}{c}(2) \\
\text { Fixed } \\
\text { effects }\end{array}$ & $\begin{array}{c}(3) \\
\text { Fixed } \\
\text { effects }\end{array}$ & $\begin{array}{c}(1) \\
\text { Fixed } \\
\text { effects }\end{array}$ & $\begin{array}{c}(2) \\
\text { Fixed } \\
\text { effects }\end{array}$ & $\begin{array}{c}(3) \\
\text { Fixed } \\
\text { effects }\end{array}$ & $\begin{array}{c}(1) \\
\text { Fixed } \\
\text { effects }\end{array}$ & $\begin{array}{c}(2) \\
\text { Fixed } \\
\text { effects }\end{array}$ & $\begin{array}{c}(3) \\
\text { Fixed } \\
\text { effects }\end{array}$ \\
\hline \multicolumn{10}{|c|}{ Incentive variables } \\
\hline CashComp & $\begin{array}{l}2.08^{* *} \\
(2.44)\end{array}$ & $\begin{array}{l}1.66^{\text {*** }} \\
(2.22)\end{array}$ & $\begin{array}{l}1.65^{* *} \\
(2.19)\end{array}$ & $\begin{array}{l}0.91^{\text {** }} \\
(2.31)\end{array}$ & $\begin{array}{l}0.76^{* *} \\
(2.08)\end{array}$ & $\begin{array}{l}0.75^{* *} \\
(2.07)\end{array}$ & $\begin{array}{l}1.13^{* *} \\
(2.60)\end{array}$ & $\begin{array}{l}0.99^{* *} \\
(2.41)\end{array}$ & $\begin{array}{l}0.97^{* *} \\
(2.37)\end{array}$ \\
\hline Delta & $\begin{array}{c}0.49 \\
(1.19)\end{array}$ & . & $\begin{array}{c}0.03 \\
(0.17)\end{array}$ & $\begin{array}{c}0.26 \\
(1.28)\end{array}$ & . & $\begin{array}{c}0.09 \\
(0.66)\end{array}$ & $\begin{array}{c}0.32 \\
(1.34)\end{array}$ & . & $\begin{array}{c}0.15 \\
(1.30)\end{array}$ \\
\hline Vega & . & $\begin{array}{l}1.32^{* * *} \\
(3.52)\end{array}$ & $\begin{array}{l}1.31^{* * *} \\
(3.42)\end{array}$ & . & $\begin{array}{l}0.52^{* * *} \\
(3.57)\end{array}$ & $\begin{array}{l}0.49^{* * * *} \\
(3.35)\end{array}$ & . & $\begin{array}{l}0.52^{* * *} \\
(3.45)\end{array}$ & $\begin{array}{l}0.48^{* * * *} \\
(3.28)\end{array}$ \\
\hline \multicolumn{10}{|c|}{ Control variables } \\
\hline Size & $\begin{array}{l}-0.96^{*} \\
(-1.76)\end{array}$ & $\begin{array}{c}-1.20^{* * *} \\
(-2.16)\end{array}$ & $\begin{array}{l}-1.12^{* *} \\
(-2.31)\end{array}$ & $\begin{array}{c}-0.25 \\
(-0.69)\end{array}$ & $\begin{array}{c}-0.29 \\
(-0.82)\end{array}$ & $\begin{array}{c}-0.34 \\
(-1.01)\end{array}$ & $\begin{array}{c}-0.33 \\
(-0.84)\end{array}$ & $\begin{array}{c}-0.32 \\
(-0.86)\end{array}$ & $\begin{array}{c}-0.42 \\
(-1.14)\end{array}$ \\
\hline$B M$ & $\begin{array}{c}-0.09 \\
(-0.10)\end{array}$ & $\begin{array}{c}-0.25 \\
(-0.33)\end{array}$ & $\begin{array}{c}-0.24 \\
(-0.32)\end{array}$ & $\begin{array}{c}0.59 \\
(1.14)\end{array}$ & $\begin{array}{c}0.52 \\
(1.04)\end{array}$ & $\begin{array}{c}0.53 \\
(1.05)\end{array}$ & $\begin{array}{c}0.35 \\
(0.67)\end{array}$ & $\begin{array}{c}0.27 \\
(0.53)\end{array}$ & $\begin{array}{c}0.29 \\
(0.58)\end{array}$ \\
\hline Leverage & $\begin{array}{l}2.72^{* *} \\
(1.80)\end{array}$ & $\begin{array}{c}2.46^{*} \\
(1.66)\end{array}$ & $\begin{array}{l}2.46^{*} \\
(1.65)\end{array}$ & $\begin{array}{c}0.48 \\
(0.53)\end{array}$ & $\begin{array}{c}0.37 \\
(0.42)\end{array}$ & $\begin{array}{c}0.37 \\
(0.42)\end{array}$ & $\begin{array}{c}0.78 \\
(0.85)\end{array}$ & $\begin{array}{c}0.68 \\
(0.75)\end{array}$ & $\begin{array}{c}0.68 \\
(0.75)\end{array}$ \\
\hline FirmAge & $\begin{array}{l}0.74^{* * *} \\
(4.66)\end{array}$ & $\begin{array}{l}0.67^{* * *} \\
(4.57)\end{array}$ & $\begin{array}{l}0.67^{\text {*** }} \\
(4.63)\end{array}$ & $\begin{array}{l}0.30^{* * *} \\
(4.67)\end{array}$ & $\begin{array}{l}0.28^{\text {**** }} \\
(4.34)\end{array}$ & $\begin{array}{l}0.28^{* * * *} \\
(4.46)\end{array}$ & $\begin{array}{c}0.30^{* * *} \\
(4.38)\end{array}$ & $\begin{array}{l}0.27^{* * *} \\
(3.94)\end{array}$ & $\begin{array}{l}0.28^{* * *} \\
(4.10)\end{array}$ \\
\hline$R O A$ & $\begin{array}{l}-7.40^{\text {** }} \\
(-3.03)\end{array}$ & $\begin{array}{l}-7.24^{* * *} \\
(-3.01)\end{array}$ & $\begin{array}{l}-7.24^{* * *} \\
(-3.01)\end{array}$ & $\begin{array}{l}-5.19^{* * *} \\
(-2.75)\end{array}$ & $\begin{array}{l}-5.11^{* * *} \\
(-2.73)\end{array}$ & $\begin{array}{l}-5.13^{* * *} \\
(-2.76)\end{array}$ & $\begin{array}{l}-6.25^{\text {*** }} \\
(-3.56)\end{array}$ & $\begin{array}{l}-6.16^{* * *} \\
(-3.53)\end{array}$ & $\begin{array}{c}-6.20^{\text {**** }} \\
(-3.57)\end{array}$ \\
\hline Returns & $\begin{array}{c}0.46 \\
(0.62)\end{array}$ & $\begin{array}{c}0.76 \\
(1.23)\end{array}$ & $\begin{array}{c}0.75 \\
(1.20)\end{array}$ & $\begin{array}{l}0.38^{* *} \\
(2.29)\end{array}$ & $\begin{array}{l}0.51^{\text {*** }} \\
(3.39)\end{array}$ & $\begin{array}{l}0.49^{* * *} \\
(3.24)\end{array}$ & $\begin{array}{c}0.25 \\
(1.57)\end{array}$ & $\begin{array}{l}0.38^{* *} \\
(2.62)\end{array}$ & $\begin{array}{l}0.35^{\text {*** }} \\
(2.38)\end{array}$ \\
\hline Capital & $\begin{array}{l}-5.15^{*} \\
(-2.97)\end{array}$ & $\begin{array}{l}-4.87^{* * *} \\
(-2.77)\end{array}$ & $\begin{array}{l}-4.86^{* * *} \\
(-2.78)\end{array}$ & $\begin{array}{c}-1.52 \\
(-1.01)\end{array}$ & $\begin{array}{c}-1.44 \\
(-0.99)\end{array}$ & $\begin{array}{l}-1.41 \\
(-0.97)\end{array}$ & $\begin{array}{c}-2.07 \\
(-1.28)\end{array}$ & $\begin{array}{c}-2.02 \\
(-1.28)\end{array}$ & $\begin{array}{c}-1.96 \\
(-1.24)\end{array}$ \\
\hline Intangibles & $\begin{array}{c}-0.81 \\
(-0.43)\end{array}$ & $\begin{array}{c}-0.92 \\
(-0.48)\end{array}$ & $\begin{array}{c}-0.93 \\
(-0.48)\end{array}$ & $\begin{array}{c}1.09 \\
(0.46)\end{array}$ & $\begin{array}{c}1.08 \\
(0.45)\end{array}$ & $\begin{array}{c}1.05 \\
(0.44)\end{array}$ & $\begin{array}{c}-0.29 \\
(-0.12)\end{array}$ & $\begin{array}{c}-0.28 \\
(-0.12)\end{array}$ & $\begin{array}{c}-0.33 \\
(-0.14)\end{array}$ \\
\hline$\sigma C F O$ & $\begin{array}{c}0.93 \\
(0.12)\end{array}$ & $\begin{array}{c}1.72 \\
(0.28)\end{array}$ & $\begin{array}{c}1.68 \\
(0.27)\end{array}$ & $\begin{array}{l}11.43^{*} \\
(1.82)\end{array}$ & $\begin{array}{l}11.83^{*} \\
(1.88)\end{array}$ & $\begin{array}{l}11.71^{*} \\
(1.87)\end{array}$ & $\begin{array}{l}10.56 \\
(1.61)\end{array}$ & $\begin{array}{l}11.06^{*} \\
(1.68)\end{array}$ & $\begin{array}{l}10.86^{*} \\
(1.65)\end{array}$ \\
\hline oSales & $\begin{array}{l}3.77^{* * *} \\
(2.68)\end{array}$ & $\begin{array}{l}3.42^{* * *} \\
(2.44)\end{array}$ & $\begin{array}{l}3.41^{* *} \\
(2.40)\end{array}$ & $\begin{array}{l}1.41^{*} \\
(1.84)\end{array}$ & $\begin{array}{l}1.31^{*} \\
(1.70)\end{array}$ & $\begin{array}{l}1.28^{*} \\
(1.68)\end{array}$ & $\begin{array}{l}1.79^{\text {*** }} \\
(2.26)\end{array}$ & $\begin{array}{l}1.72^{* * *} \\
(2.14)\end{array}$ & $\begin{array}{l}1.66^{* *} \\
(2.09)\end{array}$ \\
\hline Fixed effects & Yes & Yes & Yes & Yes & Yes & Yes & Yes & Yes & Yes \\
\hline$R^{2}(\%)$ & 40.26 & 40.64 & 40.64 & 38.27 & 38.39 & 38.39 & 37.26 & 37.36 & 37.37 \\
\hline
\end{tabular}




\section{Table 4}

Risk-taking incentives and restatements

This table presents results from estimating a probit model of the likelihood of an accounting restatement (Restatement) as a function of equity incentives and control variables. Panel A presents results from a pooled regression using either a probit model or a linear probability model (LPM), and Panel B presents results after including firm fixed effects. All variables are as defined in Appendix A. $t$-statistics appear in parentheses and are based on standard errors clustered by firm and year. ${ }^{* * * * * *}$, and ${ }^{*}$ denote statistical significance at the $0.01,0.05$, and 0.10 levels (two-tail), respectively. Sample includes 20,445 firm-years. Sample descriptive characteristics are found in Table 2.

\section{Panel A: Pooled regression}

\begin{tabular}{|c|c|c|c|c|}
\hline Variable & $\begin{array}{c}(1) \\
\text { Probit }\end{array}$ & $\begin{array}{c}(2) \\
\text { Probit }\end{array}$ & $\begin{array}{l}\text { (3) } \\
\text { Probit }\end{array}$ & $\begin{array}{c}(4) \\
\text { LPM } \\
\text { w/ ranks }\end{array}$ \\
\hline \multicolumn{5}{|c|}{ Incentive variables } \\
\hline CashComp & $\begin{array}{c}0.16 \\
(1.57)\end{array}$ & $\begin{array}{c}0.10 \\
(0.95)\end{array}$ & $\begin{array}{c}0.09 \\
(0.89)\end{array}$ & $\begin{array}{c}0.01 \\
(0.82)\end{array}$ \\
\hline Delta & $\begin{array}{c}0.08^{* * * *} \\
(3.52)\end{array}$ & . & $\begin{array}{c}0.04 \\
(1.31)\end{array}$ & $\begin{array}{c}0.01 \\
(1.32)\end{array}$ \\
\hline Vega & . & $\begin{array}{c}0.19^{* * *} \\
(4.66)\end{array}$ & $\begin{array}{c}0.18^{* * * *} \\
(4.23)\end{array}$ & $\begin{array}{c}0.03^{* * * *} \\
(3.28)\end{array}$ \\
\hline \multicolumn{5}{|c|}{ Control variables } \\
\hline Size & $\begin{array}{c}0.02 \\
(0.61)\end{array}$ & $\begin{array}{l}-0.03 \\
(-0.55)\end{array}$ & $\begin{array}{c}-0.04 \\
(-0.85)\end{array}$ & $\begin{array}{c}0.00 \\
(-0.07)\end{array}$ \\
\hline$B M$ & $\begin{array}{l}0.19^{* * *} \\
(2.30)\end{array}$ & $\begin{array}{l}0.18^{* *} \\
(2.02)\end{array}$ & $\begin{array}{l}0.19^{* * *} \\
(2.18)\end{array}$ & $\begin{array}{c}0.00 \\
(0.18)\end{array}$ \\
\hline Leverage & $\begin{array}{c}0.13 \\
(0.64)\end{array}$ & $\begin{array}{c}0.13 \\
(0.62)\end{array}$ & $\begin{array}{c}0.16 \\
(0.73)\end{array}$ & $\begin{array}{c}0.00 \\
(0.10)\end{array}$ \\
\hline FirmAge & $\begin{array}{l}-0.01^{* * *} \\
(-3.96)\end{array}$ & $\begin{array}{c}-0.01^{* * * *} \\
(-4.14)\end{array}$ & $\begin{array}{c}-0.01 * * * \\
(-3.92)\end{array}$ & $\begin{array}{c}-0.03^{* * *} \\
(-2.86)\end{array}$ \\
\hline$R O A$ & $\begin{array}{c}0.03 \\
(-0.12)\end{array}$ & $\begin{array}{c}-0.04 \\
(-0.16)\end{array}$ & $\begin{array}{l}-0.05 \\
(-0.20)\end{array}$ & $\begin{array}{c}-0.04^{* * * *} \\
(-2.81)\end{array}$ \\
\hline Returns & $\begin{array}{c}0.08^{*} \\
(1.72)\end{array}$ & $\begin{array}{c}0.13^{* * *} \\
(3.04)\end{array}$ & $\begin{array}{c}0.12^{* * * * *} \\
(2.86)\end{array}$ & $\begin{array}{c}0.01 \\
(0.61)\end{array}$ \\
\hline Capital & $\begin{array}{c}-0.94^{* * *} \\
(-4.45)\end{array}$ & $\begin{array}{c}-0.87^{* * * *} \\
(-4.08)\end{array}$ & $\begin{array}{c}-0.86^{* * *} \\
(-4.06)\end{array}$ & $\begin{array}{c}-0.03^{* * *} \\
(-2.59)\end{array}$ \\
\hline Intangibles & $\begin{array}{c}0.13 \\
(0.76)\end{array}$ & $\begin{array}{c}0.03 \\
(0.19)\end{array}$ & $\begin{array}{c}0.05 \\
(0.23)\end{array}$ & $\begin{array}{c}0.01 \\
(0.67)\end{array}$ \\
\hline Financing & $\begin{array}{l}-0.03 \\
(-0.16)\end{array}$ & $\begin{array}{l}-0.02 \\
(-0.13)\end{array}$ & $\begin{array}{c}-0.03 \\
(-0.21)\end{array}$ & $\begin{array}{c}0.01^{*} \\
(1.65)\end{array}$ \\
\hline Acquisition & $\begin{array}{c}0.01 \\
(0.21)\end{array}$ & $\begin{array}{c}0.03 \\
(0.60)\end{array}$ & $\begin{array}{c}0.03 \\
(0.54)\end{array}$ & $\begin{array}{c}0.00 \\
(-0.17)\end{array}$ \\
\hline InterestCov & $\begin{array}{c}0.16^{* * * *} \\
(3.43)\end{array}$ & $\begin{array}{l}0.14^{* * * *} \\
(2.90)\end{array}$ & $\begin{array}{c}0.14^{* * * *} \\
(2.91)\end{array}$ & $\begin{array}{c}-0.01 \\
(-0.46)\end{array}$ \\
\hline$R^{2}(\%)$ & 6.43 & 7.50 & 7.55 & 1.76 \\
\hline
\end{tabular}


Table 4

Risk-taking incentives and restatements (cont'd)

Panel B: Firm fixed effects

(1) (2) (3)

\begin{tabular}{lccc} 
Variable & Fixed effects & Fixed effects & Fixed effect \\
\hline Incentive variables & & & \\
CashComp & $0.03^{* * *}$ & $0.02^{* * *}$ & $0.02^{* * *}$ \\
\multirow{2}{*}{ Delta } & $(4.63)$ & $(4.43)$ & $(4.44)$ \\
& 0.004 &. & 0.001 \\
Vega & $(1.46)$ &. & $(0.28)$ \\
&. & $0.01^{* * *}$ & $0.01^{* * *}$ \\
&. & $(4.17)$ & $(3.90)$
\end{tabular}

Control variables

$\begin{array}{lccc}\text { Size } & 0.01^{* * *} & 0.01^{* * *} & 0.01^{* *} \\ \text { BM } & (2.85) & (2.90) & (2.54)^{* *} \\ & 0.03^{* * *} & 0.03^{* * *} & 0.03^{* * *} \\ \text { Leverage } & (2.88) & (2.85) & (2.88) \\ & 0.04^{*} & 0.04^{*} & 0.04^{*} \\ \text { FirmAge } & (1.85)^{* *} & (1.80)^{* * *} & (1.80)^{* * *} \\ & -0.003^{* *} & -0.003^{* *} & -0.003^{* *} \\ \text { ROA } & (-2.42) & (-2.88) & (-2.98) \\ & 0.04^{*} & -0.04^{* *} & -0.04^{* *} \\ \text { Returns } & (-1.94) & (-2.05) & (-2.05) \\ & 0.01 & 0.01^{*} & 0.01^{*} \\ \text { Capital } & (1.00) & (1.74) & (1.73) \\ & -0.03 & -0.03 & -0.03 \\ \text { Intangibles } & (-1.00) & (-0.94) & (-0.93) \\ & 0.02 & 0.02 & 0.02 \\ \text { Financing } & (0.69) & (0.67) & (0.66) \\ & -0.002 & -0.002 & -0.002 \\ \text { Acquisition } & (-0.24) & (-0.18) & (-0.19) \\ & 0.001 & 0.001 & 0.001 \\ \text { InterestCov } & (0.09) & (0.16) & (0.15) \\ & 0.004 & 0.004 & 0.004 \\ \text { Fixed effects } & (1.43) & (1.12) & (1.13) \\ R^{2} \text { (\%) } & \text { Yes } & \text { Yes } & \text { Yes } \\ & 46.19 & 46.31 & 46.31 \\ & & & \end{array}$




\section{Table 5}

Risk-taking incentives and SEC Enforcement Releases

This table presents results from estimating the likelihood of an SEC Accounting and Auditing Enforcement Release $(A A E R)$ as a function of equity incentives and control variables. Panel A presents results from a pooled regression, and Panel B presents results after including firm fixed effects. All variables are as defined in Appendix A. $t$-statistics appear in parentheses and are based on standard errors clustered by firm and year. ${ }^{* * *},{ }^{* *}$, and ${ }^{*}$ denote statistical significance at the 0.01, 0.05, and 0.10 levels (two-tail), respectively. Sample includes 20,445 firm-years. Sample descriptive characteristics are found in Table 2.

Panel A: Pooled regression

\section{(1)}

Variable

Incentive variables

CashComp

Delta

Vega

$$
\begin{aligned}
& -0.03 \\
& (-0.28) \\
& 0.10^{* * *}
\end{aligned}
$$

\begin{tabular}{|c|c|c|c|c|}
\hline Size & $\begin{array}{c}0.13^{\text {**** }} \\
(2.76)\end{array}$ & $\begin{array}{l}0.11^{* *} \\
(2.31)\end{array}$ & $\begin{array}{c}0.09^{*} \\
(1.71)\end{array}$ & $\begin{array}{c}0.02^{*} \\
(1.93)\end{array}$ \\
\hline$B M$ & $0.26^{* * *}$ & $0.22^{* * *}$ & $0.25^{* * *}$ & $\begin{array}{l}0.00 \\
-017)\end{array}$ \\
\hline Leverage & $\begin{array}{l}0.55^{* * *} \\
(2.89)\end{array}$ & $\begin{array}{l}0.48^{* *} \\
(2.39)\end{array}$ & $\begin{array}{l}0.53^{* * *} \\
(2.77)\end{array}$ & $\begin{array}{c}0.01 \\
(0.82)\end{array}$ \\
\hline FirmAge & $\begin{array}{c}-0.01^{\text {**** }} \\
(-2.59)\end{array}$ & $\begin{array}{c}-0.01^{\text {**** }} \\
(-3.00)\end{array}$ & $\begin{array}{c}-0.01^{* * * *} \\
(-2.56)\end{array}$ & $\begin{array}{l}-0.01^{* * *} \\
(-2.10)\end{array}$ \\
\hline$R O A$ & $\begin{array}{c}-0.74^{* * * *} \\
(-3.00)\end{array}$ & $\begin{array}{c}-0.71^{* * * *} \\
(-2.80)\end{array}$ & $\begin{array}{c}-0.72^{* * *} \\
(-2.88)\end{array}$ & $\begin{array}{c}-0.02^{* * *} \\
(-3.27)\end{array}$ \\
\hline Returns & $\begin{array}{c}0.04 \\
(1.04)\end{array}$ & $\begin{array}{l}0.09^{* *} \\
(2.32)\end{array}$ & $\begin{array}{l}0.07^{* * *} \\
(2.00)\end{array}$ & $\begin{array}{c}0.00 \\
(-0.37)\end{array}$ \\
\hline Capital & $\begin{array}{l}-0.83^{* * *} \\
(-3.03)\end{array}$ & $\begin{array}{l}-0.76^{* * *} \\
(-2.70)\end{array}$ & $\begin{array}{c}-0.73^{* * *} \\
(-2.65)\end{array}$ & $\begin{array}{l}-0.02^{*} \\
(-1.87)\end{array}$ \\
\hline Intangibles & $\begin{array}{c}-0.40 \\
(-1.26)\end{array}$ & $\begin{array}{c}-0.51 \\
(-1.53)\end{array}$ & $\begin{array}{c}-0.48 \\
(-1.43)\end{array}$ & $\begin{array}{c}-0.01 \\
(-0.82)\end{array}$ \\
\hline Financing & $\begin{array}{l}-0.37^{* *} \\
(-2.14)\end{array}$ & $\begin{array}{l}-0.38^{* *} \\
(-2.19)\end{array}$ & $\begin{array}{l}-0.40^{* *} \\
(-2.33)\end{array}$ & $\begin{array}{c}0.00 \\
(0.29)\end{array}$ \\
\hline Acquisition & $\begin{array}{l}0.22^{* *} \\
(2.02)\end{array}$ & $\begin{array}{l}0.22^{* *} \\
(2.06)\end{array}$ & $\begin{array}{l}0.23^{* *} \\
(2.10)\end{array}$ & $\begin{array}{c}0.01 \\
(1.51)\end{array}$ \\
\hline SalesGrowth & $\begin{array}{l}0.20^{\text {**** }} \\
(3.44)\end{array}$ & $\begin{array}{l}0.24^{* * *} \\
(4.20)\end{array}$ & $\begin{array}{l}0.22^{* * * *} \\
(3.80)\end{array}$ & $\begin{array}{l}0.01^{*} \\
(1.72)\end{array}$ \\
\hline Inventory & $\begin{array}{c}-0.22 \\
(-0.56)\end{array}$ & $\begin{array}{l}-0.10 \\
(-0.25)\end{array}$ & $\begin{array}{c}-0.13 \\
(-0.33)\end{array}$ & $\begin{array}{c}0.00 \\
(-0.63)\end{array}$ \\
\hline Receivables & $\begin{array}{c}0.54 \\
(1.32)\end{array}$ & $\begin{array}{c}0.67 \\
(1.60)\end{array}$ & $\begin{array}{c}0.69^{*} \\
(1.66)\end{array}$ & $\begin{array}{l}0.01^{* *} \\
(1.96)\end{array}$ \\
\hline$R^{2}(\%)$ & 8.28 & 8.80 & 8.99 & 1.53 \\
\hline
\end{tabular}

Control variables

\section{(2)}

(3)

(4)

Probit

Probit

$-0.07$

$(-0.64)$

-0.09
$(-0.81)$

0.07

(1.28)

$\begin{array}{ll}0.15^{* * *} & 0.13^{* * *} \\ (3.14) & (2.65)\end{array}$

$\begin{array}{ll}0.15^{* * *} & 0.13^{* * *} \\ (3.14) & (2.65)\end{array}$

(3.14)

LPM w/ ranks
0.00

$(-0.41)$

$0.01^{\text {*** }}$

(2.22)

$0.02^{\text {** }}$

(2.40) 


\section{Table 5}

Risk-taking incentives and SEC Enforcement Releases (cont'd)

Panel B: Firm fixed effects

(1)

(2)

(3)

Fixed effects Fixed effects Fixed effects

Incentive variables

CashComp

Delta

Vega

Control variables

\begin{tabular}{lccc} 
Size & $0.01^{* *}$ & $0.01^{* * *}$ & $0.01^{* *}$ \\
BM & $(2.45)$ & $(3.26)$ & $(2.25)$ \\
& $0.02^{* *}$ & $0.02^{* *}$ & $0.02^{* *}$ \\
Leverage & $(2.60)$ & $(2.49)$ & $(2.60)$ \\
& 0.02 & 0.02 & 0.02 \\
FirmAge & $(1.35)$ & $(1.19)$ & $(1.23)$ \\
& $-0.003^{* * *}$ & $-0.004^{* * *}$ & $-0.004^{* * *}$ \\
ROA & $(-4.48)$ & $(-4.84)$ & $(-4.84)$ \\
& $-0.03^{*}$ & $-0.03^{*}$ & $-0.03^{*}$ \\
Returns & $(-1.80)$ & $(-1.74)$ & $(-1.79)$ \\
& $-0.003^{*}$ & 0.0001 & -0.001 \\
Capital & $(-1.79)$ & $(0.03)$ & $(-0.89)$ \\
& -0.04 & $-0.04^{*}$ & -0.04 \\
Intangibles & $(-1.60)$ & $(-1.64)$ & $(-1.53)$ \\
Financing & 0.01 & 0.01 & 0.01 \\
& $(0.76)$ & $(0.98)$ & $(0.75)$ \\
Acquisition & -0.01 & -0.01 & -0.01 \\
& $(-1.20)$ & $(-1.07)$ & $(-1.14)$ \\
SalesGrowth & 0.01 & 0.01 & 0.01 \\
& $(0.89)$ & $(0.89)$ & $(0.89)$ \\
Inventory & 0.01 & $0.01^{*}$ & $0.01^{*}$ \\
Receivables & $(1.57)$ & $(1.94)$ & $(1.76)$ \\
& -0.03 & -0.02 & -0.02 \\
Fixed effects & $(-0.96)$ & $(-0.68)$ & $(-0.73)$ \\
$R^{2}(\%)$ & 0.05 & 0.06 & 0.06 \\
& $(1.39)$ & $(1.52)$ & $(1.48)$ \\
\hline & Yes & Yes & Yes \\
& 42.85 & 42.86 & 42.95 \\
& & &
\end{tabular}




\section{Table 6}

Matched-samples

This table presents results from utilizing two matched-pair designs. In Panel A, misreporting firms are matched to non-misreporting firms based on industry and total assets. Tabulated statistics test for a difference in CashComp, Delta, and Vega between the two samples. In Panel B, firms are matched based on a vector of control variables using propensity score matching. In Panel B, one-to-one matched-pairs are formed by estimating a propensity score as a function of control variables and minimizing the differences in propensity scores and maximizing the differences in Vega. All variables are as defined in Appendix A. $p$-values (two-tail) appear in brackets and are based on standard errors clustered by firm and year $.^{* * *},{ }^{* *}$, and ${ }^{*}$ denote statistical significance at the $0.01,0.05$, and 0.10 levels (two-tail), respectively. Sample descriptive characteristics are found in Table 2.

\section{Panel A: Industry and size matched sample}

Matching on restatement

\begin{tabular}{|c|c|c|c|c|c|c|c|c|}
\hline \multirow[b]{2}{*}{ Variable } & \multicolumn{2}{|c|}{$\begin{array}{l}\text { Misreporting firms } \\
\quad(\mathrm{N}=568)\end{array}$} & \multicolumn{2}{|c|}{$\begin{array}{l}\text { Size \& industry } \\
\text { matched sample } \\
(\mathrm{N}=568)\end{array}$} & \multicolumn{2}{|c|}{ Difference in means } & \multicolumn{2}{|c|}{$\begin{array}{l}\text { Difference in } \\
\text { medians }\end{array}$} \\
\hline & Mean & Median & Mean & Median & Diff. & $\mathrm{p}$-value & Diff. & p-value \\
\hline CashComp & 6.43 & 6.38 & 6.32 & 6.26 & $0.11^{* *}$ & {$[0.04]$} & $0.12^{*}$ & {$[0.08]$} \\
\hline Delta & 4.96 & 4.84 & 4.84 & 4.86 & 0.12 & {$[0.37]$} & -0.02 & {$[0.87]$} \\
\hline Vega & 3.59 & 3.58 & 3.19 & 3.18 & $0.40^{* * *}$ & {$[0.001]$} & $0.40^{* * * *}$ & {$[<0.001]$} \\
\hline \multicolumn{9}{|c|}{ Matching on $A A E R$} \\
\hline \multirow[b]{2}{*}{ Variable } & \multicolumn{2}{|c|}{$\begin{array}{l}\text { Misreporting firms } \\
\quad(\mathrm{N}=361)\end{array}$} & \multicolumn{2}{|c|}{$\begin{array}{l}\text { Size \& industry } \\
\text { matched sample } \\
(\mathrm{N}=361)\end{array}$} & \multicolumn{2}{|c|}{ Difference in means } & \multicolumn{2}{|c|}{$\begin{array}{l}\text { Difference in } \\
\text { medians }\end{array}$} \\
\hline & Mean & Median & Mean & Median & Diff. & $\mathrm{p}$-value & Diff. & $\mathrm{p}$-value \\
\hline CashComp & 6.53 & 6.46 & 6.52 & 6.46 & 0.01 & {$[0.87]$} & 0.003 & {$[0.97]$} \\
\hline Delta & 5.11 & 5.20 & 4.99 & 5.02 & 0.12 & {$[0.40]$} & 0.18 & {$[0.30]$} \\
\hline Vega & 3.80 & 3.82 & 3.48 & 3.43 & $0.32^{* *}$ & {$[0.02]$} & $0.39^{* *}$ & {$[0.04]$} \\
\hline
\end{tabular}


Table 6

Matched-samples (cont'd)

Panel B: Propensity score matched sample

\begin{tabular}{|c|c|c|c|c|c|c|c|c|}
\hline \multirow[b]{2}{*}{ Variable } & \multicolumn{2}{|c|}{$\begin{array}{l}\text { Treatment } \\
\text { sample } \\
(\mathrm{N}=9,709)\end{array}$} & \multicolumn{2}{|c|}{$\begin{array}{l}\text { Propensity score } \\
\text { matched sample } \\
\quad(\mathrm{N}=9,709)\end{array}$} & \multicolumn{2}{|c|}{ Difference in means } & \multicolumn{2}{|c|}{$\begin{array}{l}\text { Difference in } \\
\text { medians }\end{array}$} \\
\hline & Mean & Median & Mean & Median & Diff. & p-value & Diff. & p-value \\
\hline \multicolumn{9}{|c|}{ Variables used to estimate the propensity score } \\
\hline Size & 7.20 & 7.09 & 7.20 & 7.09 & 0.00 & {$[0.98]$} & 0.00 & {$[0.94]$} \\
\hline$B M$ & 0.50 & 0.43 & 0.50 & 0.41 & 0.00 & [0.99] & 0.01 & {$[0.36]$} \\
\hline Leverage & 0.52 & 0.53 & 0.52 & 0.53 & 0.00 & {$[0.73]$} & -0.01 & {$[0.38]$} \\
\hline FirmAge & 25.76 & 21.00 & 25.97 & 22.00 & -0.21 & {$[0.73]$} & -1.00 & {$[0.35]$} \\
\hline$R O A$ & 0.04 & 0.05 & 0.04 & 0.05 & 0.00 & {$[0.72]$} & 0.00 & {$[0.60]$} \\
\hline Returns & 0.14 & 0.06 & 0.15 & 0.09 & 0.00 & {$[0.84]$} & -0.03 & {$[0.21]$} \\
\hline Capital & 0.32 & 0.25 & 0.32 & 0.26 & 0.00 & {$[0.88]$} & -0.01 & {$[0.27]$} \\
\hline Intangibles & 0.06 & 0.02 & 0.06 & 0.01 & 0.00 & {$[0.94]$} & $0.01^{* * *}$ & {$[0.002]$} \\
\hline$\sigma C F O$ & 0.06 & 0.05 & 0.06 & 0.04 & 0.00 & {$[0.86]$} & 0.00 & {$[0.24]$} \\
\hline$\sigma$ Sales & 0.22 & 0.16 & 0.22 & 0.17 & 0.00 & {$[0.72]$} & 0.00 & {$[0.33]$} \\
\hline Financing & 0.11 & 0.04 & 0.11 & 0.04 & 0.00 & {$[0.98]$} & 0.00 & {$[0.70]$} \\
\hline Acquisition & 0.04 & 0.00 & 0.04 & 0.00 & 0.00 & {$[0.63]$} & 0.00 & NA \\
\hline InterestCov & 0.68 & 0.30 & 0.67 & 0.30 & 0.01 & {$[0.85]$} & 0.00 & [0.99] \\
\hline SalesGrowth & 0.14 & 0.09 & 0.14 & 0.10 & 0.00 & [0.97] & $-0.01^{* * *}$ & [0.002] \\
\hline Inventory & 0.12 & 0.09 & 0.12 & 0.09 & 0.00 & [0.89] & 0.00 & {$[0.98]$} \\
\hline Receivables & 0.15 & 0.13 & 0.15 & 0.13 & 0.00 & {$[0.56]$} & 0.00 & {$[0.54]$} \\
\hline CashComp & 6.34 & 6.29 & 6.22 & 6.18 & $0.12^{* * *}$ & {$[<0.001]$} & $0.11^{* * *}$ & {$[<0.001]$} \\
\hline Delta & 4.41 & 4.44 & 4.36 & 4.38 & 0.05 & {$[0.16]$} & 0.06 & {$[0.41]$} \\
\hline \multicolumn{9}{|c|}{ Risk-taking incentives } \\
\hline Vega & 3.55 & 3.49 & 2.31 & 2.30 & $1.24^{* * *}$ & {$[<0.001]$} & $1.19^{* * *}$ & {$[<0.001]$} \\
\hline \multicolumn{9}{|c|}{ Misreporting variables } \\
\hline $\begin{array}{l}\text { Discretion } \\
\text { (Modified Jones) }\end{array}$ & 13.03 & 8.99 & 11.18 & 6.84 & $1.85^{* * *}$ & {$[<0.001]$} & $2.15^{* * *}$ & {$[<0.001]$} \\
\hline Discretion & & & & & & {$[0.001]$} & $0.77^{* * * *}$ & {$[<0.001]$} \\
\hline $\begin{array}{l}\text { (Dechow-Dichev) } \\
\text { Discretion }\end{array}$ & 8.10 & 5.20 & 7.29 & 4.43 & 0.81 & [0.001] & & {$[-0.001]$} \\
\hline (McNichols) & 8.06 & 5.00 & 7.27 & 4.30 & $0.79^{* * *}$ & {$[0.002]$} & $0.70^{* * *}$ & {$[0.001]$} \\
\hline Restatement & 0.03 & 0.00 & 0.02 & 0.00 & $0.01^{* * * *}$ & [0.004] & 0.00 & NA \\
\hline$A A E R$ & 0.02 & 0.00 & 0.01 & 0.00 & $0.01^{* *}$ & {$[0.02]$} & 0.00 & NA \\
\hline
\end{tabular}




\section{Table 7}

Incremental importance of the CEO's incentives

This table presents results from estimating various measures of misreporting as a function of the equity incentives of the CEO, the top management team (including the CEO), and control variables. For parsimony, coefficients on control variables are not tabulated. All variables are as defined in Appendix A. $t$-statistics appear in parentheses and are based on standard errors clustered by firm and year. ${ }^{* * *},{ }^{* *}$, and ${ }^{*}$ denote statistical significance at the 0.01, 0.05, and 0.10 levels (two-tail), respectively. Sample includes 20,445 firm-years. Sample descriptive characteristics are found in Table 2 .

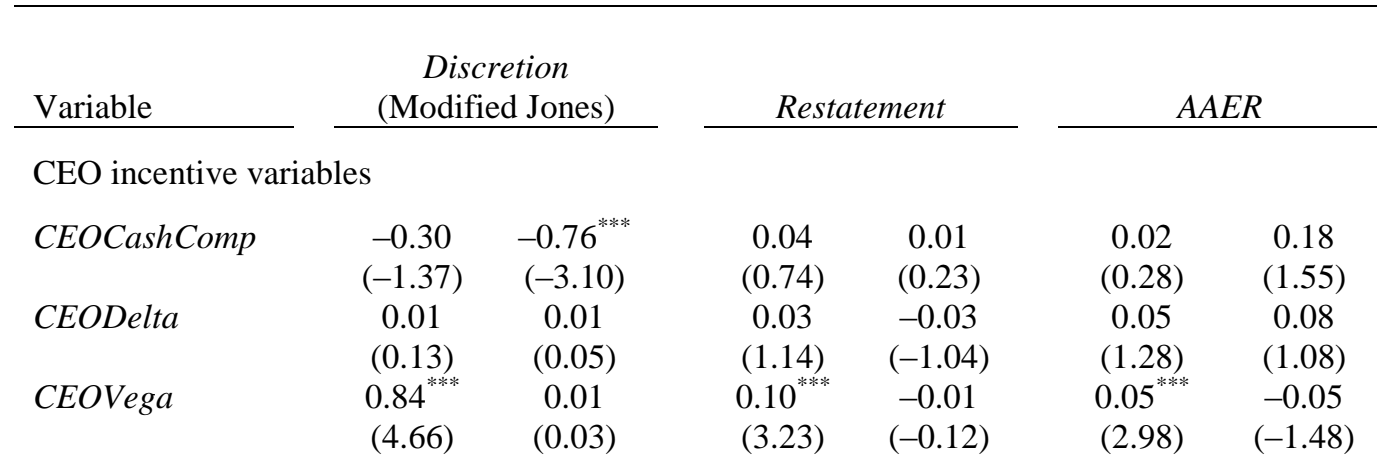

Top management team incentive variables

\begin{tabular}{|c|c|c|c|c|c|c|}
\hline CashComp & . & $\begin{array}{l}1.09^{* *} \\
(1.99)\end{array}$ & . & $\begin{array}{c}0.08 \\
(0.63)\end{array}$ & . & $\begin{array}{c}-0.29 \\
(-1.59)\end{array}$ \\
\hline Delta & . & -0.19 & . & 0.07 & . & -0.02 \\
\hline Vega & . & $\begin{array}{c}(-0.90) \\
1.36^{* * *} \\
(3.35)\end{array}$ & . & $\begin{array}{c}(1.26) \\
0.18^{* * *} \\
(3.54)\end{array}$ & . & $\begin{array}{c}(-0.25) \\
0.20^{* * *} \\
(2.81)\end{array}$ \\
\hline Controls & Yes & Yes & Yes & Yes & Yes & Yes \\
\hline$R^{2}(\%)$ & 11.05 & 11.48 & 6.91 & 7.58 & 8.71 & 9.37 \\
\hline
\end{tabular}




\section{Table 8}

Alternative portfolio sensitivity and equity incentive measures

This table presents results from estimating various measures of misreporting as a function of alternative measures of equity incentives used in the literature and control variables. Panel A presents results from deflating the Core and Guay (2002) delta (vega) by salary and separately by cash compensation (ScaledDelta, ScaledVega). Panel $\mathrm{B}$ presents results from measuring equity incentives using five alternatives measures of equity incentives: the ratio of equity-based pay to total pay (EquityComp), equity ownership (Ownership), the number of options granted during the year scaled by shares outstanding (Options), the moneyness of in-the-money options (Moneyness), and the sensitivity of portfolio delta to changes in stock price (Gamma). For parsimony, coefficients on control variables are not tabulated. All variables are as defined in Appendix A. $t$-statistics appear in parentheses and are based on standard errors clustered by firm and year. ${ }^{* * *},{ }^{* *}$, and ${ }^{*}$ denote statistical significance at the $0.01,0.05$, and 0.10 levels (two-tail), respectively. Sample includes 20,426 firm-years with non-missing values of all alternative equity incentives measures. Sample descriptive characteristics are found in Table 2.

\section{Panel A: Alternative portfolio sensitivity measures}

\begin{tabular}{|c|c|c|c|c|c|c|}
\hline \multirow[b]{2}{*}{ Variable } & \multicolumn{2}{|c|}{$\begin{array}{c}\text { Discretion } \\
\text { (Modified Jones) }\end{array}$} & \multicolumn{2}{|c|}{ Restatement } & \multicolumn{2}{|c|}{$A A E R$} \\
\hline & $\begin{array}{c}\text { Scaled by } \\
\text { salary }\end{array}$ & $\begin{array}{l}\text { Scaled by } \\
\text { cash comp. }\end{array}$ & $\begin{array}{c}\text { Scaled by } \\
\text { salary }\end{array}$ & $\begin{array}{l}\text { Scaled by } \\
\text { cash comp. }\end{array}$ & $\begin{array}{c}\text { Scaled by } \\
\text { salary }\end{array}$ & $\begin{array}{l}\text { Scaled by } \\
\text { cash comp. }\end{array}$ \\
\hline CashComp & $\begin{array}{l}0.82^{*} \\
(1.85)\end{array}$ & $\begin{array}{l}1.42^{* * *} \\
(2.79)\end{array}$ & $\begin{array}{l}0.19^{* * *} \\
(1.96)\end{array}$ & $\begin{array}{l}0.26^{* * *} \\
(2.68)\end{array}$ & $\begin{array}{c}0.01 \\
(0.07)\end{array}$ & $\begin{array}{c}0.06 \\
(0.63)\end{array}$ \\
\hline ScaledDelta & $\begin{array}{l}-0.40^{* * * *} \\
(-3.26)\end{array}$ & $\begin{array}{l}-0.44^{* * *} \\
(-2.34)\end{array}$ & $\begin{array}{l}-0.01 \\
(-0.55)\end{array}$ & $\begin{array}{l}-0.01 \\
(-0.28)\end{array}$ & $\begin{array}{l}-0.01 \\
(-0.33)\end{array}$ & $\begin{array}{l}-0.01 \\
(-0.18)\end{array}$ \\
\hline ScaledVega & $\begin{array}{l}10.42^{* * * * *} \\
(4.26)\end{array}$ & $\begin{array}{c}18.24^{* * * *} \\
(4.38)\end{array}$ & $\begin{array}{l}0.83^{* * *} \\
(3.75)\end{array}$ & $\begin{array}{l}1.46^{* * * *} \\
(3.82)\end{array}$ & $\begin{array}{l}0.60^{* *} \\
(2.21)\end{array}$ & $\begin{array}{l}1.06^{* *} \\
(2.07)\end{array}$ \\
\hline $\begin{array}{l}\text { Controls } \\
R^{2}(\%)\end{array}$ & $\begin{array}{c}\text { Yes } \\
1114\end{array}$ & $\begin{array}{c}\text { Yes } \\
1126\end{array}$ & $\begin{array}{l}\text { Yes } \\
6.95\end{array}$ & $\begin{array}{l}\text { Yes } \\
690\end{array}$ & Yes & Yes \\
\hline
\end{tabular}

Panel B: Alternative measures of equity incentives

\begin{tabular}{|c|c|c|c|c|c|c|}
\hline \multirow{2}{*}{$\begin{array}{l}\text { Variable } \\
\text { CashComp }\end{array}$} & \multicolumn{2}{|c|}{$\begin{array}{c}\text { Discretion } \\
\text { (Modified Jones) }\end{array}$} & \multicolumn{2}{|c|}{ Restatement } & \multicolumn{2}{|c|}{$A A E R$} \\
\hline & $\begin{array}{l}1.24^{* *} \\
(2.40)\end{array}$ & $\begin{array}{c}0.41 \\
(1.02)\end{array}$ & $\begin{array}{l}0.25^{* * *} \\
(2.60)\end{array}$ & $\begin{array}{c}0.16 \\
(1.58)\end{array}$ & $\begin{array}{c}0.03 \\
(0.26)\end{array}$ & $\begin{array}{l}-0.02 \\
(-0.22)\end{array}$ \\
\hline EquityComp & $\begin{array}{l}1.49^{* *} \\
(2.30)\end{array}$ & $\begin{array}{c}0.47 \\
(0.95)\end{array}$ & $\begin{array}{l}0.25^{* * *} \\
(3.46)\end{array}$ & $\begin{array}{l}0.20^{* * * * *} \\
(2.98)\end{array}$ & $\begin{array}{l}0.25^{* * *} \\
(2.76)\end{array}$ & $\begin{array}{l}0.22^{* *} \\
(2.52)\end{array}$ \\
\hline Ownership & $\begin{array}{c}0.01 \\
(0.06)\end{array}$ & $\begin{array}{c}0.07 \\
(0.59)\end{array}$ & $\begin{array}{l}-0.02 \\
(-1.06)\end{array}$ & $\begin{array}{l}-0.08 \\
(-1.03)\end{array}$ & $\begin{array}{l}0.03 \\
(1.27)\end{array}$ & $\begin{array}{c}0.02 \\
(0.38)\end{array}$ \\
\hline Options & $\begin{array}{l}-0.32 \\
(-0.29)\end{array}$ & $\begin{array}{l}-2.45^{* * *} \\
(-2.14)\end{array}$ & $\begin{array}{c}0.06 \\
(0.54)\end{array}$ & $\begin{array}{l}-0.18 \\
(-1.38)\end{array}$ & $\begin{array}{c}0.47^{* * * *} \\
(3.05)\end{array}$ & $\begin{array}{l}0.35^{* *} \\
(2.07)\end{array}$ \\
\hline Moneyness & $\begin{array}{c}0.0001 \\
(0.01)\end{array}$ & $\begin{array}{l}-0.0001 \\
(-0.01)\end{array}$ & $\begin{array}{l}0.002^{* *} \\
(2.32)\end{array}$ & $\begin{array}{l}0.002^{* * *} \\
(2.05)\end{array}$ & $\begin{array}{c}0.002^{* * * *} \\
(3.40)\end{array}$ & $\begin{array}{c}0.002^{* * * *} \\
(3.18)\end{array}$ \\
\hline Gamma & $\begin{array}{l}-0.18 \\
(-1.03)\end{array}$ & $\begin{array}{l}-0.51 \\
(-1.41)\end{array}$ & $\begin{array}{l}-0.02 \\
(-0.52)\end{array}$ & $\begin{array}{l}-0.07 \\
(-1.56)\end{array}$ & $\begin{array}{l}-0.01 \\
(-0.23)\end{array}$ & $\begin{array}{l}-0.03 \\
(-0.62)\end{array}$ \\
\hline Delta & & $\begin{array}{l}-0.13 \\
(-0.61)\end{array}$ & & $\begin{array}{c}0.14 \\
(1.20)\end{array}$ & & $\begin{array}{c}0.03 \\
(0.50)\end{array}$ \\
\hline Vega & & $\begin{array}{l}1.75^{* * *} \\
(4.88)\end{array}$ & & $\begin{array}{l}0.18^{* * *} \\
(3.75)\end{array}$ & & $\begin{array}{l}0.10^{* *} \\
(2.53)\end{array}$ \\
\hline $\begin{array}{l}\text { Controls } \\
R^{2}(\%)\end{array}$ & $\begin{array}{c}\text { Yes } \\
10.21\end{array}$ & $\begin{array}{c}\text { Yes } \\
11.97\end{array}$ & $\begin{array}{l}\text { Yes } \\
7.09\end{array}$ & $\begin{array}{l}\text { Yes } \\
7.23\end{array}$ & $\begin{array}{l}\text { Yes } \\
9.86\end{array}$ & $\begin{array}{l}\text { Yes } \\
9.98\end{array}$ \\
\hline
\end{tabular}




\section{Table 9}

\section{Sources of vega}

This table presents results from decomposing vega into various components. Panel A present results from decomposing vega into the portion correlated with recent stock performance, and the portion uncorrelated with recent stock performance. VegaPerf (VegaNonPerf) is the predicted value (residual) from a regression of Vega on Returns, estimated for each firm with at least five years of data. Panel B presents results from decomposing total portfolio vega (Vega) into vega from existing option holdings (VegaOld) and vega from option grants during the year (VegaNew), and further decomposing vega from option grants during the year into the vega of option grants on the day of the grant (GrntDtVegaNew), and the change in vega between the grant date and the end of the year (ChngVegaNew). VegaNew is the natural logarithm of one plus the sensitivity of options granted to the top five executives in the current year to a 0.01 change in stock volatility, VegaOld is Vega minus VegaNew, GrntDtVegaNew is the natural logarithm of one plus the sensitivity of options granted to the top five executives in the current year to a 0.01 change in stock volatility calculated using stock price on each grant date, and ChngVegaNew is VegaNew minus GrntDtVegaNew. All other variables are as defined in Appendix A. For parsimony, coefficients on control variables are not tabulated. $t$-statistics appear in parentheses and are based on standard errors clustered by firm and year. ${ }^{* * *},{ }^{* *}$, and ${ }^{*}$ denote statistical significance at the $0.01,0.05$, and 0.10 levels (two-tail), respectively. Sample includes 18,405 firm-years in Panel A and 20,445 firm-years in Panel B.

Panel A: Performance-related vega

\begin{tabular}{|c|c|c|c|}
\hline Variable & $\begin{array}{c}\text { Discretion } \\
\text { (Modified Jones) }\end{array}$ & Restatement & $A A E R$ \\
\hline CashComp & $\begin{array}{c}0.30 \\
(0.82)\end{array}$ & $\begin{array}{c}0.08 \\
(0.72)\end{array}$ & $\begin{array}{l}-0.08 \\
(-0.74)\end{array}$ \\
\hline Delta & $\begin{array}{l}-0.24 \\
(-1.44)\end{array}$ & $\begin{array}{c}0.04 \\
(1.31)\end{array}$ & $\begin{array}{c}0.07 \\
(1.34)\end{array}$ \\
\hline VegaPerf & $\begin{array}{l}0.70^{* * *} \\
(2.87)\end{array}$ & $\begin{array}{l}0.14^{* *} \\
(2.25)\end{array}$ & $\begin{array}{l}0.11^{*} \\
(1.64)\end{array}$ \\
\hline VegaNonPerf & $\begin{array}{l}2.35^{* * *} \\
(5.04)\end{array}$ & $\begin{array}{l}0.21^{* * * *} \\
(4.11)\end{array}$ & $\begin{array}{l}0.15^{* * *} \\
(2.02)\end{array}$ \\
\hline $\begin{array}{l}\text { Controls } \\
R^{2}(\%)\end{array}$ & $\begin{array}{c}\text { Yes } \\
12.79\end{array}$ & $\begin{array}{l}\text { Yes } \\
7.95\end{array}$ & $\begin{array}{l}\text { Yes } \\
9.60\end{array}$ \\
\hline
\end{tabular}

Panel B: Vega from current year grants

\begin{tabular}{|c|c|c|c|c|c|c|}
\hline \multirow{2}{*}{$\begin{array}{l}\text { Variable } \\
\text { CashComp }\end{array}$} & \multicolumn{2}{|c|}{$\begin{array}{c}\text { Discretion } \\
\text { (Modified Jones) }\end{array}$} & \multicolumn{2}{|c|}{ Restatement } & \multicolumn{2}{|c|}{$A A E R$} \\
\hline & $\begin{array}{c}0.19 \\
(0.49)\end{array}$ & $\begin{array}{c}0.19 \\
(0.47)\end{array}$ & $\begin{array}{c}0.09 \\
(0.84)\end{array}$ & $\begin{array}{c}0.09 \\
(0.83)\end{array}$ & $\begin{array}{l}-0.09 \\
(-0.87)\end{array}$ & $\begin{array}{l}-0.09 \\
(-0.89)\end{array}$ \\
\hline Delta & $\begin{array}{l}-0.16 \\
(-0.96)\end{array}$ & $\begin{array}{l}-0.16 \\
(-0.97)\end{array}$ & $\begin{array}{c}0.03 \\
(1.22)\end{array}$ & $\begin{array}{c}0.03 \\
(1.21)\end{array}$ & $\begin{array}{c}0.07 \\
(1.32)\end{array}$ & $\begin{array}{c}0.07 \\
(1.30)\end{array}$ \\
\hline VegaOld & $\begin{array}{l}1.78^{* * *} \\
(4.80)\end{array}$ & $\begin{array}{l}1.77^{* * * *} \\
(4.88)\end{array}$ & $\begin{array}{l}0.17^{* * * *} \\
(3.63)\end{array}$ & $\begin{array}{l}0.17^{* * * *} \\
(3.64)\end{array}$ & $\begin{array}{c}0.08 \\
(1.58)\end{array}$ & $\begin{array}{c}0.08 \\
(1.51)\end{array}$ \\
\hline VegaNew & $\begin{array}{l}1.17^{* * *} \\
(3.90)\end{array}$ & & $\begin{array}{l}0.20^{* * * *} \\
(4.61)\end{array}$ & & $\begin{array}{l}0.16^{* * * *} \\
(2.97)\end{array}$ & \\
\hline GrntDtVegaNew & & $\begin{array}{l}1.16^{* * *} \\
(3.87)\end{array}$ & & $\begin{array}{l}0.20^{* * * *} \\
(4.63)\end{array}$ & & $\begin{array}{l}0.16^{* * *} \\
(3.01)\end{array}$ \\
\hline ChngVegaNew & & $\begin{array}{c}1.61 \\
(1.09)\end{array}$ & & $\begin{array}{c}0.29 \\
(1.07)\end{array}$ & & $\begin{array}{c}0.37 \\
(1.57)\end{array}$ \\
\hline Controls & Yes & Yes & Yes & Yes & Yes & Yes \\
\hline$R^{2}(\%)$ & 11.59 & 11.61 & 7.74 & 7.75 & 9.36 & 9.40 \\
\hline
\end{tabular}




\section{Table 10}

Analysis of the vega-delta wedge

This table reports the characteristics of firms in the top percentile of the vega-delta wedge. The vega-delta wedge is calculated for each firm-year as the difference between $D F B E T A_{\text {Vega }}$ and DFBETA $A_{\text {Delta. }}$ DFBETA $A_{\text {Vega }}\left(D F B E T A_{\text {Delta }}\right)$ is calculated for each measures of misreporting as the change in the regression coefficient on Vega (Delta) from including the respective firm-year in the third regression specification in Panel A of each of Tables 3, 4, and 5, respectively. This table reports mean values of variables used in our analyses for observations in the top percentile of the wedge, for all other observations, and the difference in means. OptionEquityRatio is the ratio of option holdings of the top five executives to the total equity holdings (stock and options) of the top five executives. All other variables are as defined in Appendix A. ${ }^{* * *},{ }^{* *}$, and ${ }^{*}$ denote statistical significance at the $0.01,0.05$, and 0.10 levels (two-tail), respectively. Sample includes 20,445 firm-years.

\begin{tabular}{|c|c|c|c|c|c|c|c|c|c|}
\hline \multirow[b]{2}{*}{ Variable } & \multicolumn{3}{|c|}{ Discretion (Modified Jones) } & \multicolumn{3}{|c|}{ Restatement } & \multicolumn{3}{|c|}{$A A E R$} \\
\hline & Top $1 \%$ & Others & Diff. & Top $1 \%$ & Others & Diff. & Top $1 \%$ & Others & Diff. \\
\hline \multicolumn{10}{|l|}{ Misreporting variables } \\
\hline Discretion (Modified Jones) & 50.65 & 11.82 & $38.83^{* * *}$ & 18.56 & 12.14 & $6.41^{* * * *}$ & 13.63 & 12.19 & $1.44^{*}$ \\
\hline Discretion (Dechow-Dichev) & 16.94 & 7.66 & $9.28^{* * *}$ & 9.98 & 7.73 & $2.25^{* * *}$ & 8.43 & 7.75 & 0.68 \\
\hline Discretion (McNichols) & 18.10 & 7.63 & $10.47^{* * *}$ & 9.77 & 7.72 & $2.05^{* * *}$ & 8.60 & 7.73 & 0.87 \\
\hline Restatement & 0.06 & 0.03 & $0.03^{*}$ & 1.00 & 0.02 & $0.98^{* * *}$ & 0.32 & 0.02 & $0.29^{* * *}$ \\
\hline$A A E R$ & 0.02 & 0.02 & 0.01 & 0.18 & 0.02 & $0.16^{* * *}$ & 0.89 & 0.01 & $0.88^{* * * *}$ \\
\hline \multicolumn{10}{|l|}{ Incentive variables } \\
\hline CashComp & 6.26 & 6.29 & -0.03 & 6.42 & 6.29 & $0.12^{* * *}$ & 6.49 & 6.29 & $0.19^{* * *}$ \\
\hline Delta & 4.42 & 4.46 & -0.04 & 4.66 & 4.46 & $0.20^{* *}$ & 5.23 & 4.46 & $0.78^{* * *}$ \\
\hline Vega & 3.04 & 2.95 & 0.09 & 3.97 & 2.95 & $1.02^{* * *}$ & 3.95 & 2.95 & $1.00^{* * *}$ \\
\hline Ownership & 1.52 & 1.34 & 0.18 & 1.09 & 1.34 & $-0.26^{* * *}$ & 1.28 & 1.34 & -0.06 \\
\hline OptionEquityRatio & 0.78 & 0.71 & $0.07^{* * *}$ & 0.88 & 0.71 & $0.18^{* * *}$ & 0.83 & 0.71 & $0.12^{* * *}$ \\
\hline \multicolumn{10}{|l|}{ Control variables } \\
\hline Size & 7.14 & 7.27 & -0.13 & 7.42 & 7.27 & 0.15 & 8.05 & 7.26 & $0.78^{* * *}$ \\
\hline$B M$ & 0.46 & 0.50 & -0.03 & 0.46 & 0.50 & $-0.04^{* *}$ & 0.43 & 0.50 & $-0.07^{* * * *}$ \\
\hline Leverage & 0.51 & 0.52 & -0.01 & 0.46 & 0.52 & $-0.06^{* * *}$ & 0.55 & 0.52 & $0.03^{*}$ \\
\hline FirmAge & 22.05 & 26.12 & $-4.08^{* * * *}$ & 21.33 & 26.13 & $-4.81^{* * *}$ & 22.87 & 26.12 & $-3.25^{* * * *}$ \\
\hline$R O A$ & -0.01 & 0.04 & $-0.05^{* *}$ & 0.04 & 0.04 & 0.00 & 0.01 & 0.04 & $-0.03^{* *}$ \\
\hline Returns & 0.19 & 0.14 & 0.05 & 0.26 & 0.14 & $0.11^{* *}$ & 0.24 & 0.14 & 0.10 \\
\hline Capital & 0.31 & 0.32 & -0.01 & 0.22 & 0.32 & $-0.10^{* * * *}$ & 0.22 & 0.32 & $-0.10^{* * *}$ \\
\hline Intangibles & 0.06 & 0.06 & 0.00 & 0.11 & 0.06 & $0.05^{* * *}$ & 0.06 & 0.06 & 0.00 \\
\hline Financing & 0.09 & 0.11 & -0.01 & 0.13 & 0.11 & 0.02 & 0.11 & 0.11 & 0.01 \\
\hline$\sigma C F O$ & 0.07 & 0.06 & $0.01^{*}$ & 0.08 & 0.06 & $0.02^{* * *}$ & 0.07 & 0.06 & 0.01 \\
\hline oSales & 0.24 & 0.22 & 0.02 & 0.24 & 0.22 & $0.03^{*}$ & 0.25 & 0.22 & $0.03^{* *}$ \\
\hline Acquisition & 0.03 & 0.04 & -0.01 & 0.03 & 0.04 & -0.01 & 0.14 & 0.04 & $0.09^{* * * *}$ \\
\hline InterestCov & 0.75 & 0.67 & 0.08 & 0.64 & 0.67 & -0.04 & 0.81 & 0.67 & $0.14^{* *}$ \\
\hline SalesGrowth & 0.12 & 0.14 & -0.02 & 0.11 & 0.14 & $-0.03^{* *}$ & 0.31 & 0.14 & $0.17^{* * *}$ \\
\hline Inventory & 0.08 & 0.12 & $-0.04^{* * * *}$ & 0.08 & 0.12 & $-0.03^{\text {*** }}$ & 0.09 & 0.12 & $-0.03^{* * * *}$ \\
\hline Receivables & 0.14 & 0.15 & -0.01 & 0.14 & 0.15 & $-0.01^{*}$ & 0.16 & 0.15 & $0.01^{* *}$ \\
\hline
\end{tabular}


